\title{
Review
}

\section{Blast Loaded Columns-State of the Art Review}

\author{
Sanja Lukić $(\mathbb{D}$ and Hrvoje Draganić *(C)
}

Department for Materials and Structures, Faculty of Civil Engineering and Architecture Osijek, Josip Juraj Strossmayer University of Osijek, Vladimira Preloga 3, HR-31000 Osijek, Croatia; slukic@gfos.hr

* Correspondence: draganic@gfos.hr

Citation: Lukić, S.; Draganić, $\mathrm{H}$. Blast Loaded Columns-State of the Art Review. Appl. Sci. 2021, 11, 7980. https://doi.org/10.3390/app11177980

Academic Editors: Ricardo Castedo, Lina M. López and Anastasio P. Santos

Received: 30 July 2021

Accepted: 26 August 2021

Published: 28 August 2021

Publisher's Note: MDPI stays neutral with regard to jurisdictional claims in published maps and institutional affiliations.

Copyright: (c) 2021 by the authors. Licensee MDPI, Basel, Switzerland. This article is an open access article distributed under the terms and conditions of the Creative Commons Attribution (CC BY) license (https:// creativecommons.org/licenses/by/ $4.0 /)$.

\begin{abstract}
The ever-present threat of terrorist attacks in recent decades gives way to research towards blast-resistant design of structures. Columns, as one of the main load-bearing elements in residential buildings and bridges, are becoming interesting targets in bombing attacks. Research of column blast load behavior leads toward increased safety by identifying shortcomings and problems of those elements and acting accordingly. Field tests and numerical simulations lead to the development of new blast load mitigation technics, either in the design process or as a retrofit and strengthening of existing elements. The article provides a state-of-the-art literature review of filed blast load tests and numerical simulations of a bridge and building columns.
\end{abstract}

Keywords: blast load; concrete columns; experimental testing; numerical modeling

\section{Introduction}

In the last five decades, terrorist attacks have become more frequent. There are different types of terrorist attacks, but according to data provided by the National Consortium for the Study of Terrorism and Response to Terrorism [1], in the last two decades, explosive attacks exceed $50 \%$ of the total number of incidents, shown in Figure 1 . The attacks on The Twin Towers of the World Trade Center on 11 September 2001 and bridges in California and New York have an impact on the design of structures in the United States and also in the rest of the world [2]. In every country, the transportation system is essential for performing everyday activities, so the Blue Ribbon Panel (BRP) indicates the transportation system as one of the viable targets for a bombing attack. Due to a large number of bridges worldwide, lots of potential casualties, high repair costs, and importance in everyday life, the bridges are increasingly in the focus of terrorist attacks. This is confirmed by the fact that in the last few attacks in Nigeria in 2020, seven bridges were destroyed. It is important to identify which bridges are vulnerable due to their easy accessibility to protect against attacks. Moreover, BRP states that the columns are one of the most critical components on all types of bridges [3]. As there are many types of bridges and many ways to attack the bridge, it is difficult to predict the construction's response to the blast loadings [4]. When detonation of an explosion is under the bridge, then columns are exposed to large lateral forces, depending on standoff distance, which can result in large deformations leading to flexural or shear failures. The contact explosion can breach the column to render it incapable of supporting the dead loads. For small standoff distance, blast waves can cause a serious reduction in a concrete cross-section in terms of spalling and cratering. Since the column failure depends on the position and amount of explosives, all examined attack scenarios were observed.

The main objective of this review article is an extensive literature overview of experimental and numerical research conducted on blast-loaded columns. Both building and bridge columns are considered due to differences in their static and blast behavior. A systematic summary is given of column behavior, possible damage and failure modes, and a review of software used for blast load simulation and analysis. 


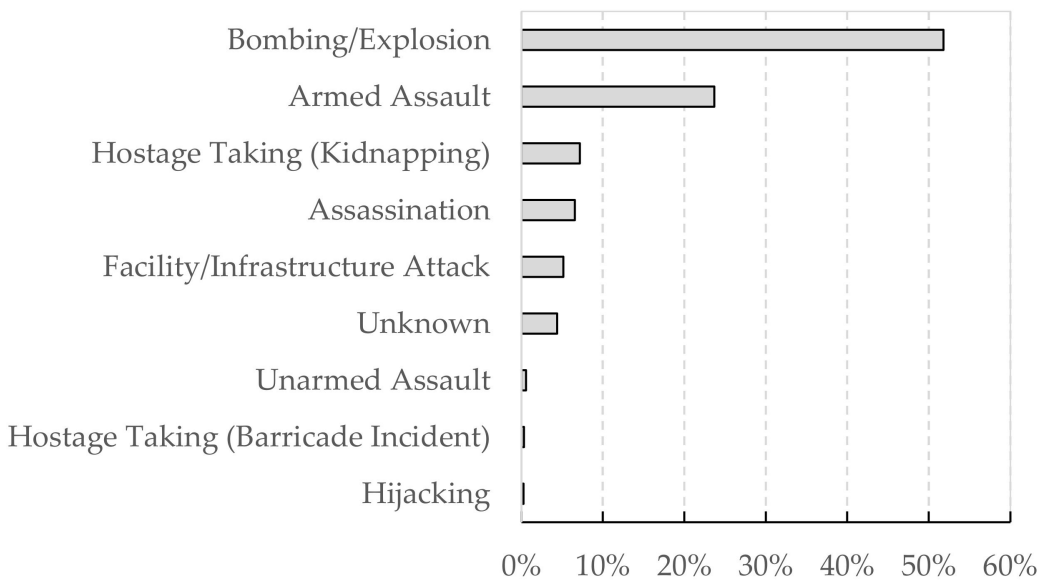

Figure 1. Percentages of terrorist attack types, based on data from [1].

\section{Experimental Testing}

There are no experiments on real scale specimens of bridge columns due to the experimental setup complexity and high costs, while the building columns are mainly conducted in full scale due to their maximum height of 2.5 to $3 \mathrm{~m}$. Moreover, these types of experiments require special testing ground (usually military field ranges) and trained personnel for handling explosives. Even these special testing grounds have limitations regarding the maximum amount of explosives that can be used in one detonation. This also limits the scale of specimens. Research conducted in recent decades has shown that scale tests provide reliable results and the necessary knowledge to analyze the effects of blast load on full-scale structures [5].

If considering building and bridge columns, except specimen dimensions, there is a difference in their behaviors due to different levels of axial load capacity. Therefore, it is recommended to analyze bridge and building columns separately [4]. A list of conducted experimental research is provided in Table 1.

Table 1. Summary of experimental research.

\begin{tabular}{|c|c|c|c|c|c|}
\hline Author & Year & Structural Element & Experiment Type & Material & Scale \\
\hline Bruneau et al. [6] & 2006 & Multicolumn bents & Field & CFCSC & $1: 4$ \\
\hline Fujikura et al. [7] & 2008 & Multicolumn bents & Field & CFST & $1: 4$ \\
\hline Davis et al. [8] & 2009 & Bridge column & Field & $\mathrm{RC}$ & S. s. $+1: 2$ \\
\hline Fujikura and Bruneau [9] & 2010 & Multicolumn bents & Field & RC and RC SJ & $1: 4$ \\
\hline Williamson et al. [4] & 2011 & Bridge column & Field & $\mathrm{RC}$ & $1: 2$ \\
\hline Crawford [10] & 2013 & Building column & Field & $\mathrm{RC}+\mathrm{FRP}+\mathrm{SJ}$ & $1: 1$ \\
\hline Burrell et al. [11] & 2015 & Column & Shock tube & SFRC & $1: 2$ \\
\hline Zhang et al. [12] & 2015 & Building column & Field & CFST & $1: 1$ \\
\hline Aoude et al. [13] & 2015 & Building column & Shock tube & UHPFRC & $1: 1$ \\
\hline Codina et al. [14] & 2016 & Building column & Field & $\mathrm{RC}$ & $1: 1$ \\
\hline Codina et al. $[15,16]$ & 2016 & Building column & Field & $\begin{array}{c}\mathrm{RC}, \mathrm{RC} \text { SJ, RC + } \\
\text { polyurethane bricks }\end{array}$ & $1: 1$ \\
\hline Xu et al. [17] & 2016 & Column & Field & UHPFRC + HSRC & $1: 1$ \\
\hline Echevarria et al. [18] & 2016 & Bridge column & Field & $\mathrm{CFFT}+\mathrm{RC}$ & $1: 5$ \\
\hline Fouché et al. [5] & 2016 & Multicolumn bents & Field & RC MSJ & $1: 4$ \\
\hline Wang et al. [19] & 2016 & Column & Filed & RPC-FST & $1: 1$ \\
\hline Zhang et al. [20] & 2016 & Column & Field & $\begin{array}{c}\text { CFDST infilled with } \\
\text { UHPC }\end{array}$ & $1: 1$ \\
\hline Zhang et al. [21] & 2017 & Column & Field & CFDST & $1: 1$ \\
\hline Codina et al. [22] & 2017 & Building column & Field & $\begin{array}{l}\mathrm{RC}+\text { reinforced resin } \\
\text { panels }\end{array}$ & $1: 1$ \\
\hline Yuan et al. [23] & 2017 & Bridge column & Field & $\mathrm{RC}$ & $1: 3$ \\
\hline Wang et al. [24] & 2017 & Building column & Field & CFST & $1: 1$ \\
\hline
\end{tabular}


Table 1. Cont.

\begin{tabular}{|c|c|c|c|c|c|}
\hline Author & Year & Structural Element & Experiment Type & Material & Scale \\
\hline Li et al. [25] & 2017 & Building column & Field & UHPC + HSRC & $1: 1$ \\
\hline Fouché et al. [26] & 2017 & Bridge column & Field & CFDST & $1: 4$ \\
\hline Dua et al. [27] & 2018 & Column & Field & $\mathrm{RC}$ & $1: 1$ \\
\hline Dua et al. [28] & 2019 & Column & Field & $\mathrm{RC}$ & $1: 1$ \\
\hline Wang et al. [29] & 2020 & Bridge column & Field & UHPCC-FST & $1: 4$ \\
\hline Kadhom et al. [30] & 2020 & Column & Shock tube & $\mathrm{RC}$ and $\mathrm{RC}+\mathrm{CFRP}$ & $1: 2$ \\
\hline Vapper and Lasn [31] & 2020 & Building column & Filed & $\mathrm{RC}, \mathrm{RC}+\mathrm{GFRP}$ & $1: 2$ \\
\hline
\end{tabular}

Note: CFCSC - Concrete-Filled Circular Steel Columns, CFST-Concrete-Filled Steel Tube, RC—Reinforced Concrete, SJ-Steel Jacket, MSJ—Modified Steel Jacket, FRP—Fiber-Reinforced Plastic, SFRC—Steel Fiber-Reinforced Concrete, UHPFRC—Ultra-High Performance Fiber Reinforced Concrete, HSRC - High Strength Reinforced Concrete, CFDST—Concrete-Filled Double-Skin Tubes, UHPC-UltraHigh Performance Concrete, SFRP—Steel Fiber Reinforced Polymer, UHPFRC—Ultra-High-Performance Fiber-Reinforced Concrete, CFFT—Concrete-Filled Fiber-Reinforced Polymer (FRP) tube, RPC-FST—Reactive Powder Concrete Filled Steel Tubular, HSRC-High Strength Reinforced Concrete, S. s.—small scale, GFRP—Glass Fiber Reinforced Polymer.

\subsection{Bridge Columns}

The experiments were carried out on standard RC columns, additionally retrofitted columns, and improved composite concrete columns. The columns are exposed to various scenarios of explosive attacks. In addition to the type of column, the scenarios also differ in the position, type, and amount of explosives.

Williamson et al. [32] provided the list of possible terrorist courses of action and indicated that the hand placed explosives on the column and large truck-bomb below the bridge superstructure can destroy columns and cause bridge collapse.

Due to similarities between the effects of the explosions and earthquakes, Bruneau et al. [6] developed a multi-hazard pier concept that they expect to provide a satisfying level of protection against failure under both loadings. All specimens were concrete-filled circular steel columns (CFCSC) with three different diameters $\left(10.16 \mathrm{~cm}\left(4^{\prime \prime}\right), 12.7 \mathrm{~cm}\left(5^{\prime \prime}\right)\right.$, $\left.15.24 \mathrm{~cm}\left(6^{\prime \prime}\right)\right)$ and a minimum steel thickness of $3.2 \mathrm{~mm}$. Specimens were made in 1:4 scale of the prototype bridge columns. Due to security reasons, the actual values of charge weights and standoff distances are not provided. Experimental results showed that even a minimal increase in standoff distance and column diameter significantly reduces column deformation. The CFCS columns showed ductile behavior and high resistance to the effects of the explosion [6]. The same scale and scenario when the explosive was located under the bridge in a car placed near to the column were examined in [7]. They assumed the charge weight similar to the blast weights predicted in FEMA (2003) [33] and FHWA (2003) [34]. Charges are set at heights of $0.25 \mathrm{~m}$ and $0.75 \mathrm{~m}$, which correspond to the actual height of $1 \mathrm{~m}$ (car bomb) and the half column height, respectively. They concluded that only steel jacketing is not enough to provide adequate resistance to the large shear forces influencing the bottom of the column. Therefore, they found that a better solution is using a fully concrete-filled steel tube (CFST) continuously embedded into the footing. CFST columns provided ductile behavior and sufficient resistance to the lateral forces from earthquakes and explosions. Moreover, the advantage of CFST columns is that they do not have a breach and a spall of concrete, i.e., they do not produce flying debris [7]. Figure 2 shows the connection concept between the foundation beam and the CFST column, which provides the full moment capacity of the column. At a rotation of $3.8^{\circ}$ of the bottom of the column, plastic deformation is visible but without cracking of the concrete. The first cracks occur at a rotation of $8.3^{\circ}$, while the fracture of the steel tube occurs at $17^{\circ}$. At the height of the explosive charge, pits and notches appeared on the steel tube, while concrete cracks occurred on the tension side at the bottom and top of the column due to the rigid boundary conditions [7]. They assumed the same blast scenario as Fujikura et al. [7] in their work at the same scale of 1:4, but there were four columns in the test specimen while the bridge prototype has three. Figure 3 shows the test setup for the same blast load scenario but on different types of columns. The RC column exhibited shear failure at the base and cracking of concrete along the column [9], RC SJ shear failure [9], and CFST column flexural failure 
and buckling [7]. Fujikura and Bruneau [9], in their work, presented experimental and analytical investigations of seismically ductile RC columns and non-ductile RC columns retrofitted with steel jackets. The charge was set to a height of $0.25 \mathrm{~m}$ which corresponds to the actual height of $1 \mathrm{~m}$ (car bomb), and at this height, the column experienced the maximum deflection. All columns failed in direct shear at the base, but RC columns with steel jackets did not experience any structural damage, and the RC column experienced spalling of concrete at the bottom. Compared to the CFST columns, these columns did not exhibit a ductile behavior.

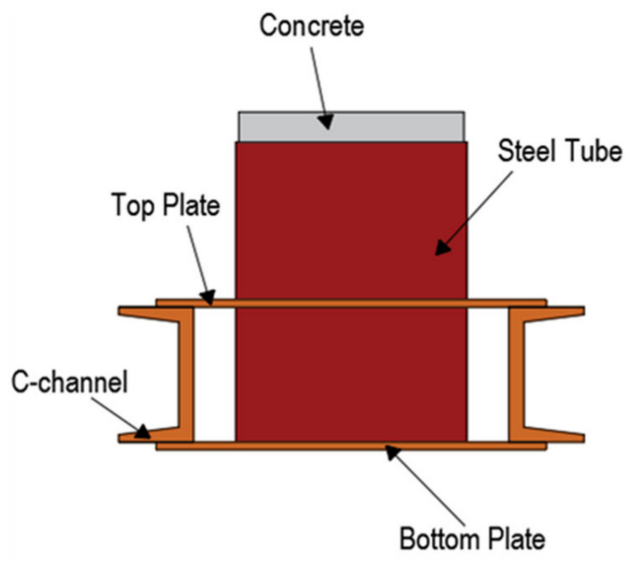

Figure 2. CFST column-details of column-to-foundation beam connection [7].

Davis et al. [8] conducted an experiment in two phases. In the first phase, they tested eight small-scale columns where they first changed the standoff distance and then the amount of explosive charge while the scaled distance was kept fixed. In the second phase, they tested 16 columns in half scale (1:2), where 10 of them were set at a small standoff to observe the mode of failure (flexure or shear) like in [4], and the remaining six were to sustain local damage (spall and breach patterns). In all samples, concrete strength, clear cover, concrete class, and reinforcement grade were unchanged. Boundary conditions for tested columns were assumed to be pinned at the top and fixed at the bottom. The test setup did not include axial load because low levels of axial loads provide greater capacity to the column, and without axial load, tests are on the conservative side. Five experimental observations and guidelines for the design of blast-loaded columns are provided in [4,8,35]:

1. Using protective fences and barriers for vehicles to increase the standoff distance;

2. The circular cross-section can maintain a lower pressure of up to $1 / 3$ concerning a square cross-section of the same dimensions, so the second guideline is to use circular columns, and also, the pressure reducing factors on the circular column were proposed by Winget et al. [2], Marchand et al. [36], and Fujikura et al. [7], respectively, as $0.80,0.75$, and 0.45 ;

3. Increase in the reinforcement in the column, as this increases the shear capacity, ductility, and confinement of the concrete;

4. Use of continuous reinforcement because discrete hoops can be extracted during a blast load;

5. Placing longitudinal splices away from the charge if they cannot be completely avoided.

They also proposed three design categories $(\mathrm{A}, \mathrm{B}, \mathrm{C})$ that depend on the scaled distance and require a different approach to designing, i.e., gravity, seismic, blast. In the $C$ category $\left(Z \leq 0.6 \mathrm{~m} / \mathrm{kg}^{1 / 3}\right)$, columns are exposed to the higher loads than columns in A $\left(Z>1.2 \mathrm{~m} / \mathrm{kg}^{1 / 3}\right)$ and $\mathrm{B}\left(0.6<Z \leq 1.2 \mathrm{~m} / \mathrm{kg}^{1 / 3}\right)$. 


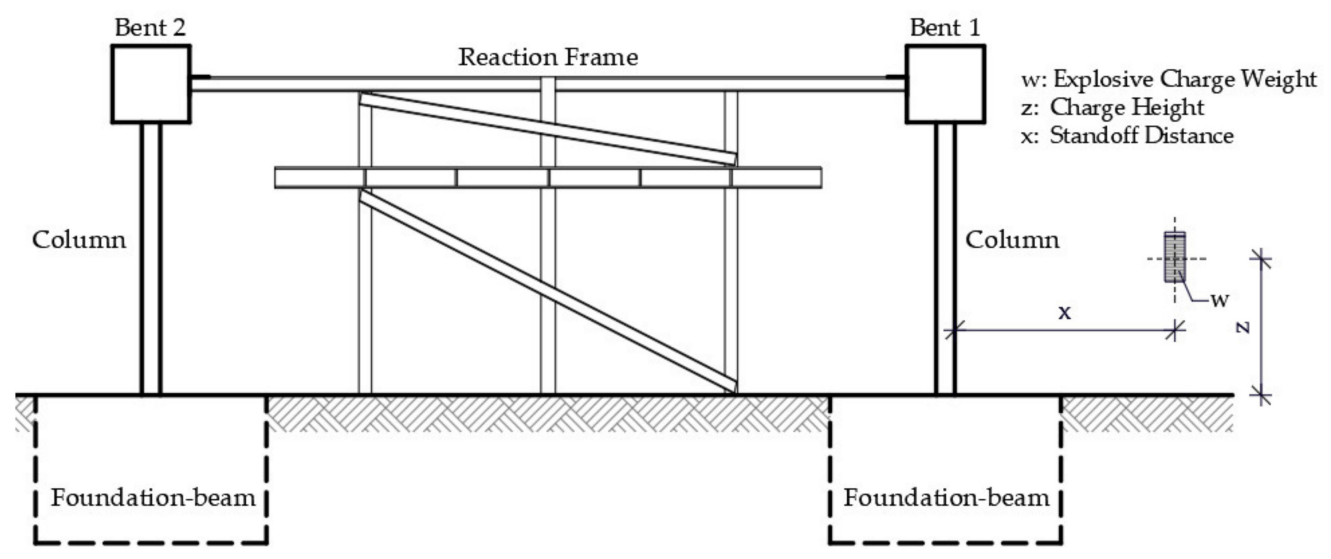

Figure 3. Test setup in [7] and [9].

Williamson et al., in Part II [35], provided a review of experiments represented in Part I [4]. Square columns experienced greater net resultant impulse than circular columns under the same blast loads and also had a larger cross-section area, so less shear occurred at the base. To increase the shear capacity of the column at the base and the ductility, it is necessary to increase the amount of transverse reinforcement. Moreover, columns with continuous spirals had a better performance than columns with discrete ties, which confirms the recommendation given in [8]. Due to changes in column design, the weight of charge, and standoff distance, several levels of damage were obtained [37,38]. The test setup is shown in Figure 4. Superficial damage means that the column performed well and has only surface damage and cracks, while minor damage means spalling of the concrete cover and cracks along the column. Deformations, flexural cracking, and spalling of concrete all together are extensive damage, while the failure of the column means that a shear occurred at the base [4].

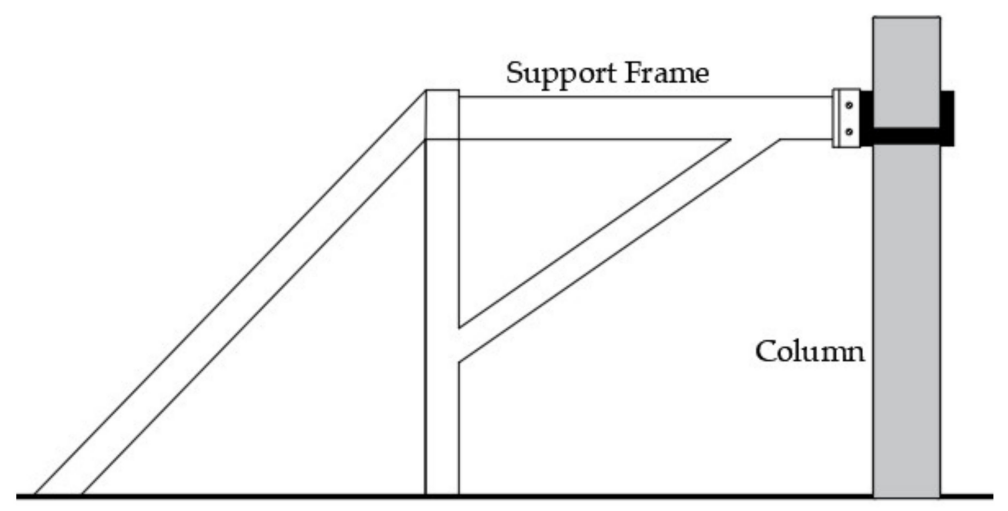

Figure 4. Test setup $[4,8]$.

Echevarria et al. [18] tested RC and Concrete-Filled Fiber-Reinforced Polymer (FRP) tube (CFFT) bridge columns at a scale of 1:5. CFFT columns are reinforced only with longitudinal reinforcement, while RC columns have spiral hoops in addition to longitudinal reinforcement, shown in Figure 5. The quantity and distance of the explosives were not provided for safety reasons. The columns experienced minimal visual damage, but measurements showed that both concrete and steel experienced large loads and strains. In the residual test, CFFT columns showed greater strength and ductility than RC columns. 


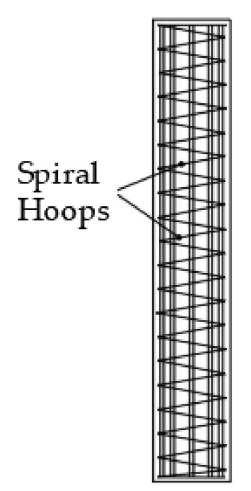

(a)

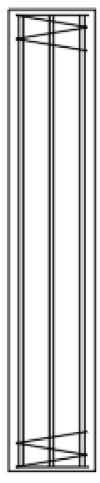

(b)

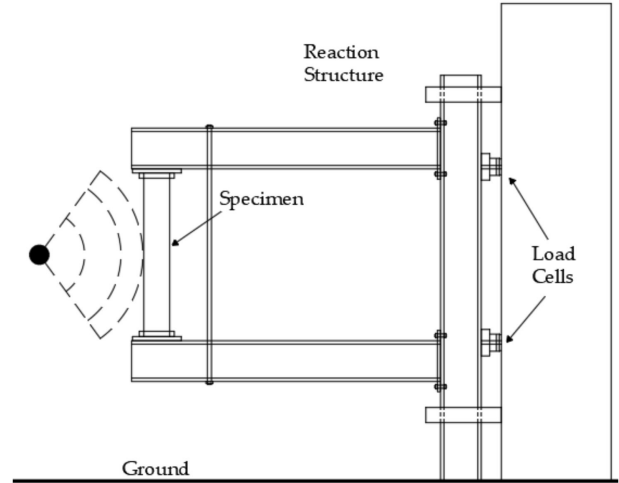

(c)

Figure 5. Reinforcement position in specimens: (a) RC column and (b) CFFT column; specimen position: (c) test setup [18].

Fouché et al. [5] made the same prototype of the bridge columns as [9] and exposed them to the same blast load scenario. To improve the behavior of the steel jacked columns to the explosion, they added structural steel collars at the top and bottom of the column. The steel collar at the base of the steel jacked RC column is shown in Figure 2 in [5]. They concluded that the modified column was effective in preventing direct shear and had increased ductility. The obtained maximum base rotation ranges from 8.6 to $10.3^{\circ}$, and all the columns showed satisfactory behavior.

Yuan et al. [23] experimentally tested two RC bridge columns in scale $1: 3$ under $1 \mathrm{~kg}$ TNT contact explosion placed at the height of $33 \mathrm{~cm}$ from the ground. As a retaining structure that prevents the rotation and displacement of the column at the top, they used a wall with the opening that was placed at a distance of $1.4 \mathrm{~m}$ from the detonation point. Both columns experienced spallation and crushing of concrete cover, but the stirrup fracture was observed only in the square column. The damages to the front and back sides of the circular and square columns are shown in Figure 13. Therefore, the test results showed that the square column had more severe damage than the circular column.

Wang et al. [29] investigated the impact of contact explosions of $1 \mathrm{~kg}, 2 \mathrm{~kg}$, and $3 \mathrm{~kg}$ of TNT on the mode of failure and original and residual axial capacity of Ultra-High Performance Cementitious Composite Filled Steel Tube (UHPCC-FST) bridge column. The columns were made in 1:4 scale and are tested horizontally, and the views of the test setup are shown in Figure 6. The top of the column is pinned, and the bottom of the column is fixed. The cylindrical explosive is placed at a distance of $25 \mathrm{~cm}$ from the lower support, which represents the actual position of the explosive in the vehicle at the height of $1 \mathrm{~m}$. Quantities of explosives of 1 and $2 \mathrm{~kg}$ made only a crater in the column, while $3 \mathrm{~kg}$ fractured the tube and crushed the core, as shown in Figure 7. In the axial compression test, all columns experienced diagonal shear failure.

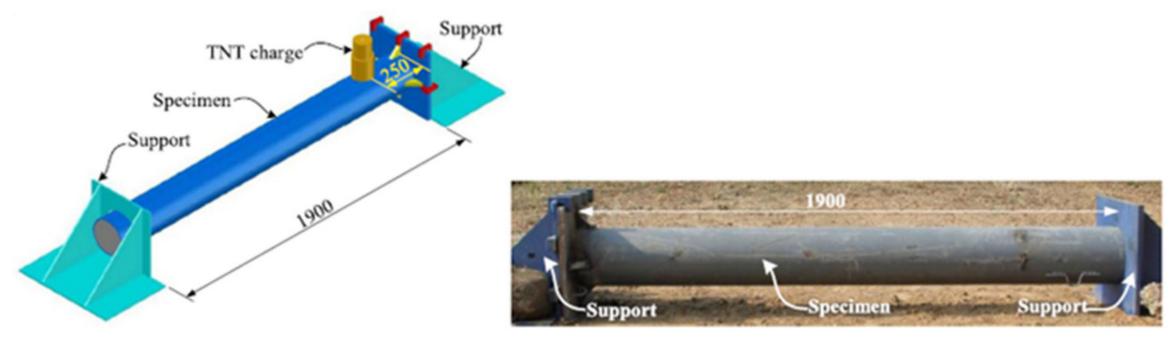

Figure 6. Schematic and field views of test setup [29]. Copyright permission obtained from authors. 


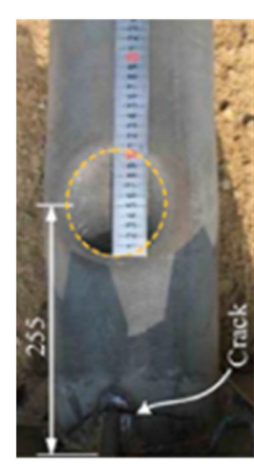

(a)

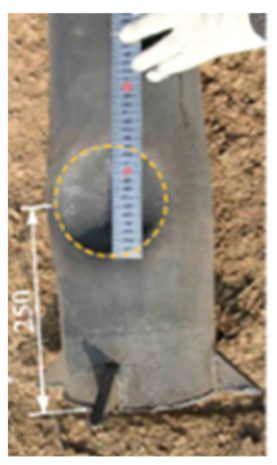

(b)

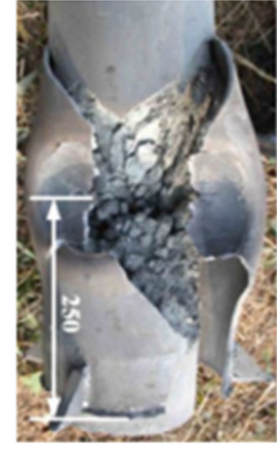

(c)

Figure 7. Damage of UHPCC-FST columns after detonation of: (a) $1 \mathrm{~kg}$; (b) $2 \mathrm{~kg}$ and (c) $3 \mathrm{~kg}$ of TNT [29]. Copyright permission obtained from authors.

Based on the reviewed literature of bridge columns, maximum support rotations in field blast tests are shown in Table 2. The information can be used as a preliminary, fast damage assessment of blast-loaded columns based on the measured post-blast column rotations.

Table 2. Maximum support rotations (blast at low height).

\begin{tabular}{|c|c|c|c|c|}
\hline & Top & Bottom & Crack Patterns of Concrete & Deformation \\
\hline \multirow{4}{*}{ CFST [7] } & $1.2^{\circ}$ & $3.8^{\circ}$ & No available & Plastic \\
\hline & $2.2^{\circ}$ & $8.3^{\circ}$ & Tension side & Plastic \\
\hline & $4.9^{\circ}$ & $17.0^{\circ}$ & Opening of core concrete & On-set of fracture of column \\
\hline & $18.7^{\circ}$ & - & Blew away & Post-fracture of column \\
\hline RC MSJ [5] & - & $8.6-10.3^{\circ}$ & Satisfactory ductile behavior & \\
\hline \multirow{3}{*}{$\operatorname{RC}[2,36,39]^{*}$} & - & $1.3^{\circ}$ & Slight to moderate damage & \\
\hline & - & $2^{\circ}$ & Moderate to heavy damage & \\
\hline & - & $3^{\circ}$ & Lose structural integrity & \\
\hline \multirow{2}{*}{$\mathrm{RC}[40]$} & - & $2^{\circ}$ & Minor damage & Onset of shear failure at base \\
\hline & - & $4^{\circ}$ & Collapse & Shear failure at base \\
\hline \multirow{2}{*}{ RC (UFC 3-340-02) [41] } & & $2-5^{\circ}$ & Moderate damage & \\
\hline & & $5-12^{\circ}$ & Severe damage & \\
\hline RC (AISC 341) [42] & & $2.3^{\circ}$ & Highly ductile & \\
\hline
\end{tabular}

* Based on experimental testing of concrete beam elements in flexure.

\subsection{Building Columns}

In addition to bridges, interesting targets of terrorist attacks are buildings. By damaging the ground floor columns, the whole building loses stability, so in most of the new buildings, the ground floor columns are designed also considering the blast loads. Building columns differ from bridge columns in the magnitude of the axial loads. Moreover, the dimensions of building columns are significantly smaller, so most of the experiments conducted on building columns were in full or half-scale.

Burrell et al. [11] tested two half-scale reinforced concrete columns and six Steel FiberReinforced Concrete columns (SFRC) with steel fiber content from 0 to $1.5 \%$ by volume of concrete (non-seismic and seismic detailing) at shock tube. In the experiment, the axial load equal to $30 \%$ load capacity was applied using a hydraulic jack. According to their experiments, columns designed seismically $(38 \mathrm{~mm}$ distance between transverse reinforcement) have smaller maximum displacements and can withstand larger blast loads. Moreover, SFRC columns with non-seismic detailing $(75 \mathrm{~mm}$ distance between transverse reinforcement) showed smaller maximum displacements and no secondary blast fragments. 
Aoude et al. [13] experimentally tested nine Ultra-High-Performance Fiber Reinforced Concrete (UHPFRC) columns designed with Compact Reinforced Composite (CRC). Tests were performed in a shock tube, and a hydraulic jack was used to input the axial load. The applied blast pressures varied from $69 \mathrm{kPa}$ to $689 \mathrm{kPa}$. Dimensions of the cross-section were $152 \mathrm{~mm} \times 152 \mathrm{~mm}$, and the free span of the column was $1980 \mathrm{~mm}$. The results showed that the UHPFRC columns reduce secondary blast fragments. Increasing the proportion of fibers from $2 \%$ to $4 \%$ had a positive effect on the decrease in displacement, but a higher proportion of fibers did not result in improvements in blast behavior.

Zhang et al. [12] experimentally blast tested three square columns and one circular column. The columns were made from steel tubes filled with concrete (CFST). Specimens were placed horizontally with a simple boundary condition at both ends. A pneumatic jack was used to input the axial load, shown in Figure 8. The entire length of the specimen was $2.5 \mathrm{~m}$. In the experiment, an emulsion explosive, which has a TNT-equivalent of 0.7 , was used. The maximum and residual column deformations are provided for blast loads utilizing 17.5 to $35 \mathrm{~kg}$ TNT equivalence at a standoff distance of $1.5 \mathrm{~m}$. The concrete inside the steel tube reduced local deformations, and the energy was dissipated through the global response of the element. Zhang et al. [20] tested two types of CFDST columns, circular and square, with inner and outer tubes, as shown in Figure 9. They concluded that columns filled with normal strength concrete experienced greater crushing of concrete and higher steel buckling than columns filled with UHPC. Moreover, UHPC proved to be very resistant to spalling or crushing. The tested CFDST and CFST samples have similar oscillation periods and displacements, so it is concluded that they behave similarly. Zhang et al. [21] tested six ultra-high-performance concrete-filled double skin tube columns with square hollow sections. At a standoff distance of $1.5 \mathrm{~m}$, the specimen exposed to $35 \mathrm{~kg}$ of TNT did not experience any localized damage or steel buckling. Moreover, the axial load ( $25 \%$ of the maximum load) contributed to the reduction in maximum deflection in the middle of the column. They concluded that the ratio of the cavity and the section influence the overall column deflection and period of oscillation; therefore, it is recommended not to go above 0.5. Wang et al. [19] exposed four circular Reactive Powder Concrete Filled Steel Tubular columns to explosion and fire durations of 0,60, and $105 \mathrm{~min}$. Fixed supports were simulated, and on one side, an axial load was introduced. Steel tube protects columns against cracks and spalling of concrete. After the detonation of the $17.5 \mathrm{~kg}$ explosive, the column experienced bending and after $35 \mathrm{~kg}$ bending-shearing deformations. With an increase in the number of explosives and with longer exposure to fire, maximum and residual displacements increased. Wang et al. [24] studied four square and four circular CFST columns under close-range blasts. The column length was $2.5 \mathrm{~m}$, and the thickness of the steel tube was $2.8 \mathrm{~mm}$ or $3.8 \mathrm{~mm}$. The standoff distance of the emulsion explosive was $1.5 \mathrm{~m}$, and the charge weight expressed through the TNT equivalence was from 25 to $50 \mathrm{~kg}$. Only a $10 \%$ increase in the amount of explosive in square columns increases mid-span deflection by $200 \%$, which is assumed to be caused by a large surface exposed to the blast load. Moreover, increasing the thickness of the steel tube by $1 \mathrm{~mm}$ (from 2.8 to $3.8 \mathrm{~mm}$ ) significantly reduced the displacement (by over $50 \%$ ). Global failure mode was a flexural failure, and after removing the steel, the square columns sustained spalling and crushing of concrete. Circular columns were broken into several parts. Figure 10 shows the damage to the concrete after removing the steel tube after the blast load. 


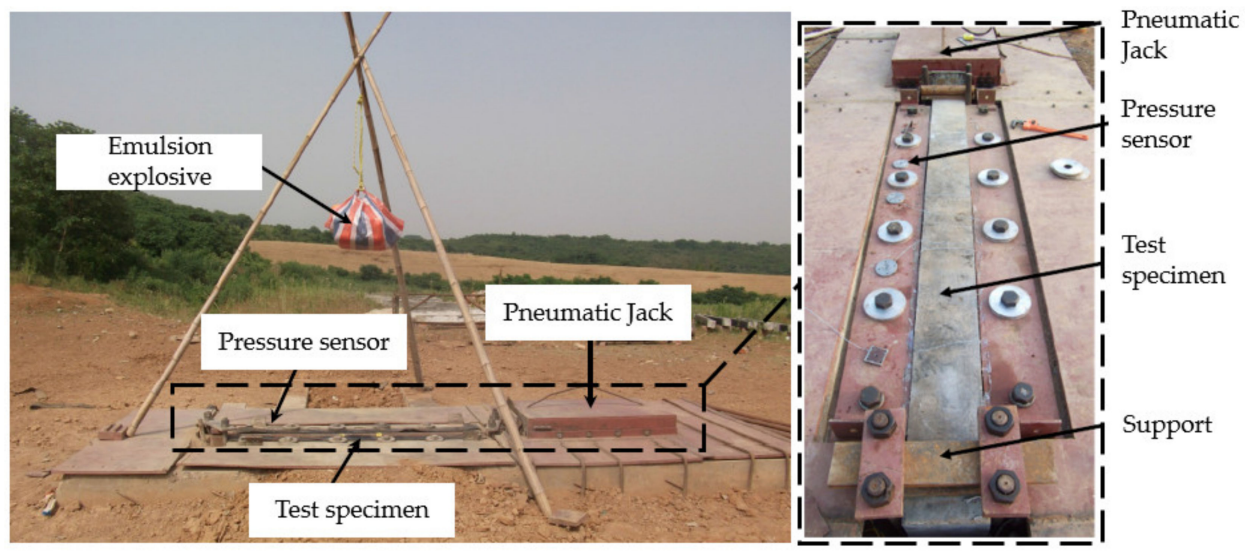

Figure 8. Test setup [24] and test pit [21]. Copyright permission obtained from authors.
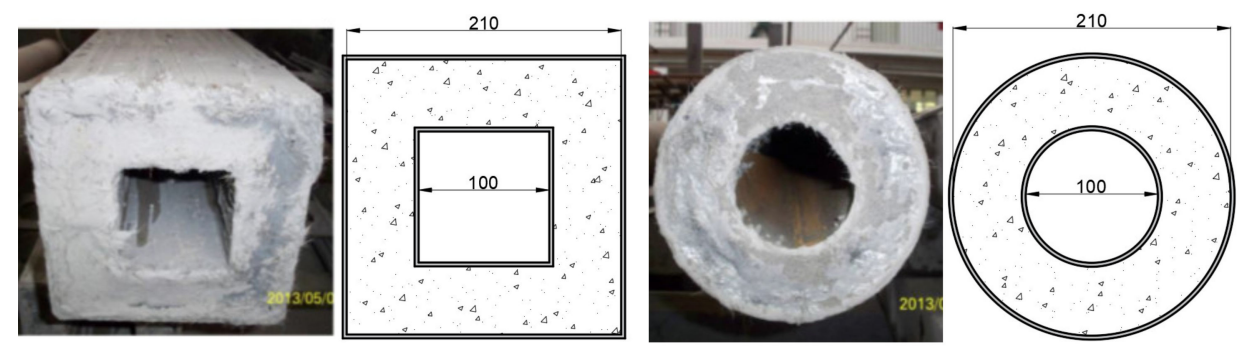

Figure 9. Cross-sections of two CFDST specimens [20]. Copyright permission obtained from authors.
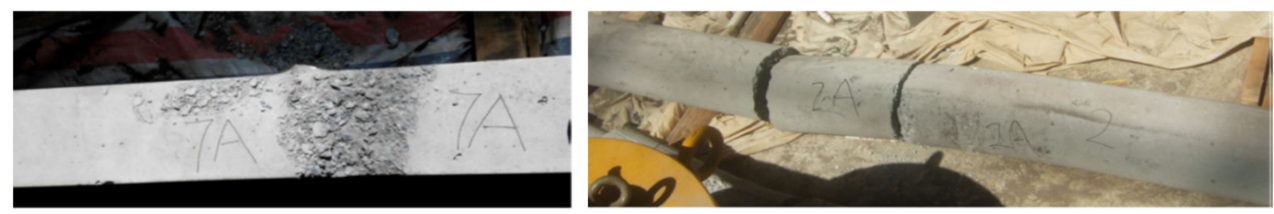

Figure 10. Columns after blast test [24]. Copyright permission obtained from authors.

Codina et al. [14] investigated the effects of close-in blast loading on the full-scale reinforced concrete column. They conducted experimental tests and numerical simulations to calibrate the numerical model. The observed column had a square cross-section of $230 \mathrm{~mm} \times 230 \mathrm{~mm}$ and a free height of $2.44 \mathrm{~m}$. The column was tested in a horizontal position, and the standoff distance from the center of the charge $(8 \mathrm{~kg}$ of equivalent TNT-the used explosive is Gelamon VF65, which is equivalent in a mass to $65 \%$ TNT) to column 1 was $100 \mathrm{~cm}$ and to column 2 was $60 \mathrm{~cm}$. Both columns experienced flexural damage, spallation of the concrete on the bottom side, and crushing of concrete on the exposed side, shown in Figure 11.

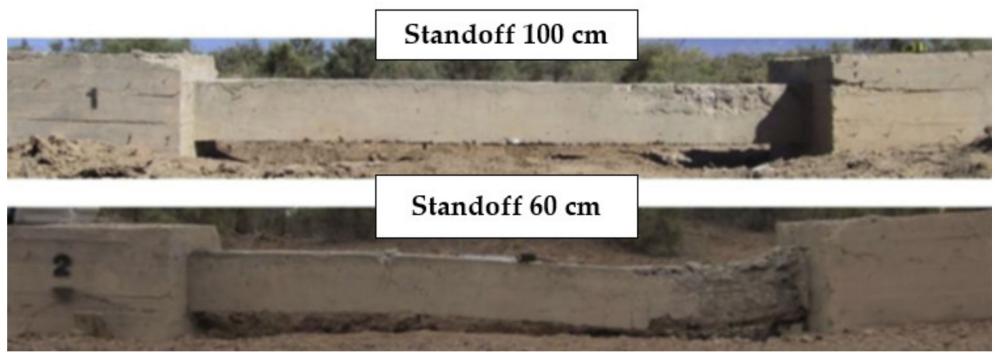

Figure 11. Damage of the RC columns after detonation at $100 \mathrm{~cm}$ and $60 \mathrm{~cm}$ standoff [14]. Copyright permission obtained from authors. 
Codina et al. $[15,16]$ investigated the behavior of RC columns and RC columns with two types of protection (steel jacket and reinforced polyurethane bricks) exposed to a near field explosion. At a standoff distance of $60 \mathrm{~cm}, 8 \mathrm{~kg}$ of TNT equivalent shaped into a cylinder was placed, resulting in a scaled distance $\mathrm{Z}=0.30 \mathrm{~m} / \mathrm{kg}^{1 / 3}$. Comparing the test results of three types of columns, the steel-jacked column had the best results in residual capacity and in reducing final deflection. Polyurethane bricks are lighter and have cheaper protection for columns but give three times worse results than steel jacketing. It is recommended to set bricks of higher density to improve the effect in the area of blast load. In [16], they also examined reinforced resin panels with insulation layers as a possible improvement of the column. This protection system gave the best results, minimizing column damage and the greatest deflection reduction. The protection system in the field test is shown in Figure 12. Codina et al. [22], after their research on plain RC columns [14], tested RC columns covered with reinforced resin panels with an insulation layer and steel jacketing. From the obtained results, it can be concluded that a significant reduction in damage and displacement was achieved with the cladding system, but the spalling and burst of concrete cannot be prevented. Figure 14 shows a schematic representation of all specimens and their damage covered by the studies of Codina et al.

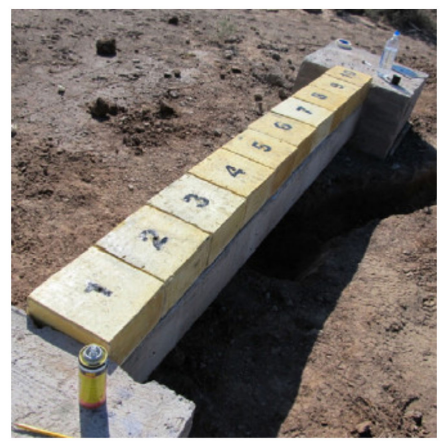

(a)

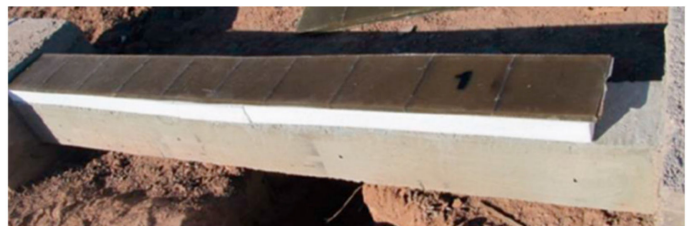

(b)

Figure 12. RC columns reinforced with: (a) polyurethane bricks $[15,16]$ and (b) resin panels and insulation layer [22]. Copyright permission obtained from authors.

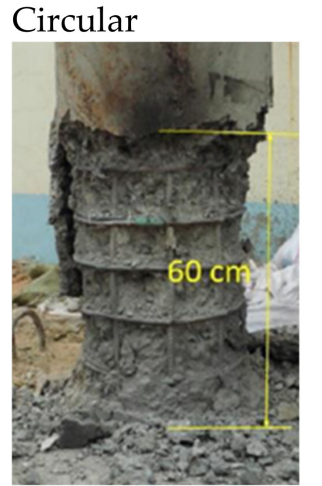

(a)

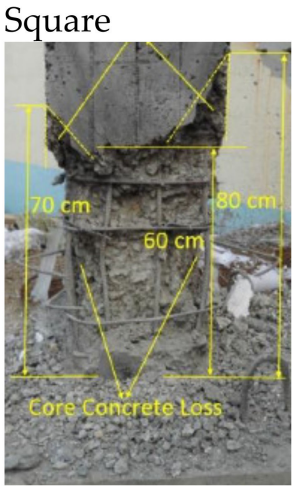

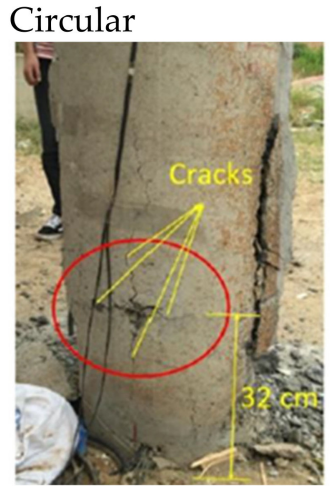

(b)

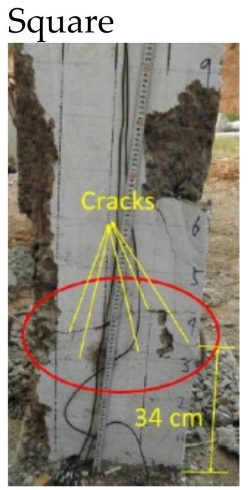

Figure 13. Comparison of damages of circular and square RC columns after the detonation of $1 \mathrm{~kg}$ of TNT: (a) front side and (b) back side [23]. Copyright permission obtained from authors. 


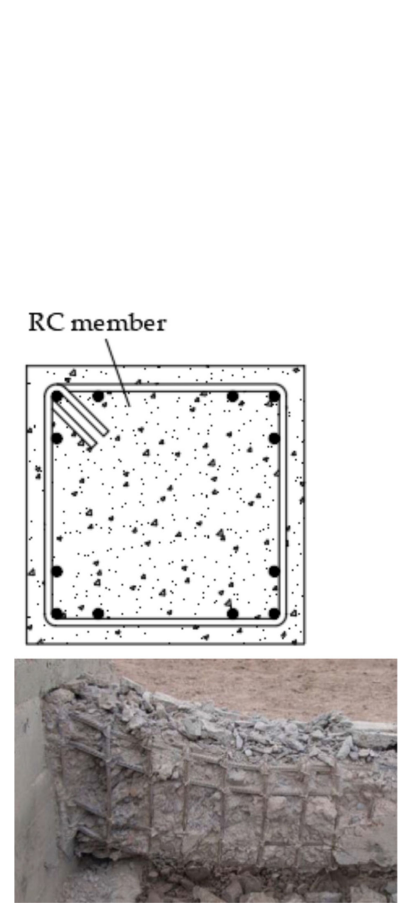

(a)

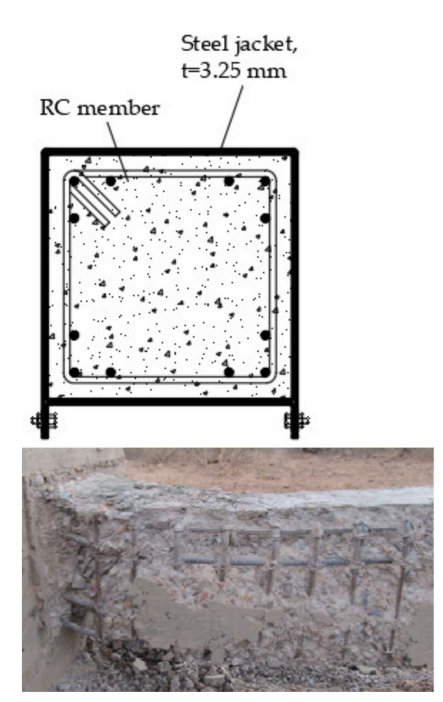

(b)

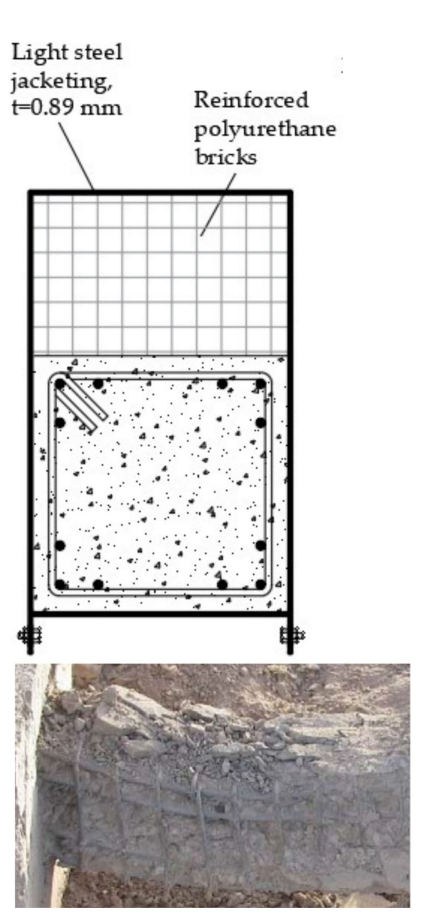

(c)

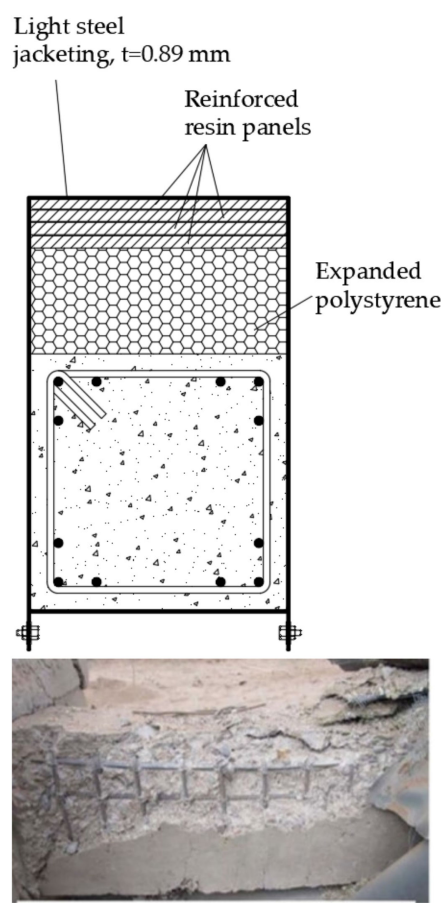

(d)

Figure 14. Damage after blast load on RC members: (a) without protection; (b) with steel jacketing; (c) with polyurethane bricks, and (d) with reinforced resin panels [15,16,22]. Copyright permission obtained from authors.

$\mathrm{Xu}$ et al. [17] subjected four Ultra-High-Performance Fiber Reinforced Concrete (UHPFRC) and four High Strength Reinforced Concrete (HSRC) square columns to the effects of blast loads. Columns were tested under varied charge weights from $1.4 \mathrm{~kg}$ to $48 \mathrm{~kg}$ of emulsion explosive (TNT equivalence factor is 1.4). The standoff distance was fixed at $1.5 \mathrm{~m}$ in all tests. Specimens were placed horizontally, and the axial load was applied using a pneumatic jack. The results showed that UHPFRC columns could better withstand overpressure and shock waves, reducing the maximum displacements.

Li et al. [25] tested 10 Ultra-High-Performance Concrete (UHPC; six reinforced with twisted fiber and four reinforced with micro fiber) and 5 High Strength Reinforced Concrete (HSRC) columns. The length of the specimens was $2.5 \mathrm{~m}$, and the cross-section was square with dimensions $0.2 \mathrm{~m} \times 0.2 \mathrm{~m}$. In experiments, the standoff distances of the explosive from the columns were constantly $1.5 \mathrm{~m}$ in all tests, but the explosive weight was changed. For the UHPC columns, weights of 17.5, 25, and $35 \mathrm{~kg}$, and for the HSRC 8, 17.5 and $25 \mathrm{~kg}$ were used. Residual load capacity tests showed that UHPC columns after blast loads did not lose much on the axial load capacity. UHCP columns also showed much better load capacity after $35 \mathrm{~kg}$ TNT detonation than HSRC columns after $8 \mathrm{~kg}$ TNT detonation.

Fouché et al. [26] experimentally tested 12 columns at a scale of 1:4 under the blast load. They varied the void ratio, diameters, and thicknesses of the outer and inner steel tubes. The specimens' cross-section generally experienced denting, and that deformation helped to energy absorption from the overpressure from the near-contact explosions. The inner steel tube played the role of a dowel preventing direct shear failure, and this is the advantage of the CFDST columns over CFST and RC columns. On the tensile side of the column, the concrete was crushed, or horizontal flexure cracks appeared.

Dua et al. [27] tested three RC columns $(30 \mathrm{~cm} \times 30 \mathrm{~cm} \times 375 \mathrm{~cm})$ in full scale with the same material and geometrical properties on contact explosion at the bottom of the column. They used $0.1 \mathrm{~kg}$ of plastic explosive (PEK-TNT equivalent 1.15 ) and $0.5 \mathrm{~kg}$ and $1 \mathrm{~kg}$ of TNT. The TNT charge of $1 \mathrm{~kg}$ made a hole in the column; $0.5 \mathrm{~kg}$ destroyed the concrete cover, and the remaining core has no residual capacity; $115 \mathrm{~g}$ TNT equivalent caused the spalling 
of the concrete cover. Column damage profiles are shown in Figure 15. A contact explosion causes significant local damage on at least three sides of the column, while a far-field explosion causes the worst damage on the front, exposed side. Dua et al. [28] investigated the same blast load scenario on the column concerning the increase in the cross-sectional width of the column. They experimentally tested columns of dimensions $50 \mathrm{~cm} \times 30 \mathrm{~cm}$, $70 \mathrm{~cm} \times 30 \mathrm{~cm}$, and $90 \mathrm{~cm} \times 30 \mathrm{~cm}$. Rectangular columns showed better behavior under contact explosion than squares. They examined the residual load-bearing capacity of the column and determined the column damage index. When the width dimension of the column subjected to the blast load is greater two and more times from depth, the damage index is lower.

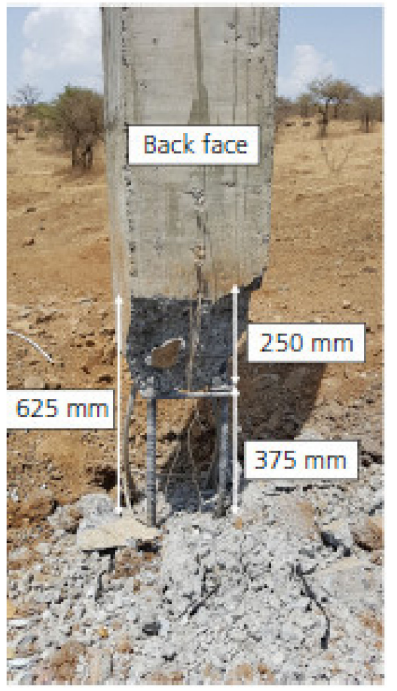

(a)

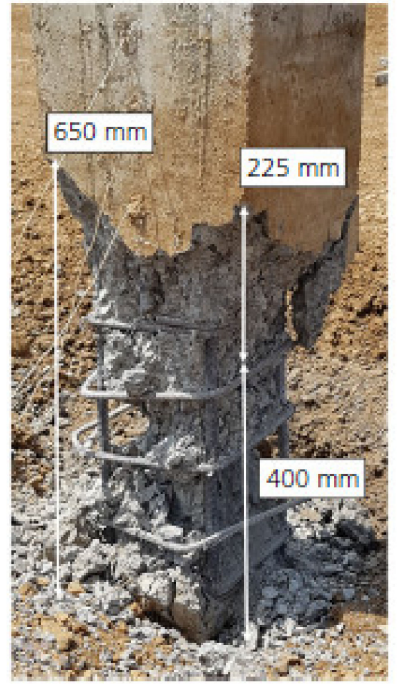

(b)

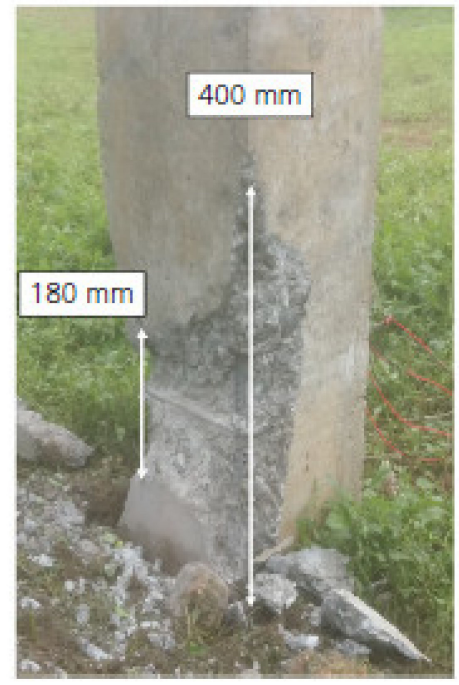

(c)

Figure 15. Column damages after blast loads: (a) $1 \mathrm{~kg}$; (b) $0.5 \mathrm{~kg}$ and (c) $115 \mathrm{~g}$ TNT [27]. Copyright permission obtained from authors.

Kadhom et al. [30] examined five half-scale RC columns. Three columns are strengthened with unidirectional and woven CFRP laminates while the other two remained unprotected. They were first tested in the shock tube on the induced blast load, and thereafter, their residual axial capacity was examined. The column strengthened with CFRP laminates with $\pm 45^{\circ}$ woven fibers showed the best blast behavior and the most ductile response.

Fujikake and Aemlaor [43] investigated how longitudinal and shear reinforcement ratios, concrete strength, and the number of explosives affect the demolition of RC building columns. Their primary research goal is not terrorist attacks but the demolition of dilapidated concrete buildings. They used a Composite 4 (C4) explosive because of its stability and ease of shaping and placed it in the core of the column. They found that shear reinforcement plays a significant role in the residual bearing capacity after blasting; the strength of the concrete also affects the increase in residual compressive and flexural resistance capacities. The quantities of explosives and reinforcement cannot be applied to the external action of the explosion, but certainly, conclusions about the role of reinforcement and the strength of concrete are useful.

Roller et al. [44] observed two scenarios: first is a contact explosion with the amount of PETN that fits in the suitcase, and the second is the close-in scenario when the explosive is in the vehicle. They investigated the impact on RC columns and strengthened columns. Polymer concrete, SIFCON (Slurry Infiltrated Fiber Concrete), DUCON (Ductile Concrete), and Ultra-High-Performance Concrete (UHPC) were used to improve the resistance of the bridge and building columns. The appearances of column damages after contact explosion and the residual load capacities are shown in Table 3. The results showed an increase in residual bearing capacity by up to $70 \%$. 
Table 3. Damaged columns after contact detonation and the residual load capacities [44].

\begin{tabular}{cccccc}
\hline & RC & Polymer Concrete & SIFCON & DUCON \\
\hline Type & & & & & \\
\hline \\
Damage
\end{tabular}

$\mathrm{Xu}$ et al. [45] tested five columns in an explosion containment vessel (ECV). The columns were exposed to an explosion of $40 \mathrm{~g}$ charge mass, and the distance of the explosive was changed in each test from a contact explosion to a standoff distance of $50 \mathrm{~cm}$. They installed four smart aggregates (SAs) in each specimen for internal damage detection, shown in Figure 16. The propagation of the stress wave energy decreases with the formation of cracks under the blast load, and hence the amplitude of the time-domain signal recorded by piezometric smart aggregate sensors decreases with the appearance of cracks. This method of detecting internal damage has proven to be useful for completing the picture of the condition of the structure because internal cracks have a greater impact on the damage index of the structure than surface cracks.

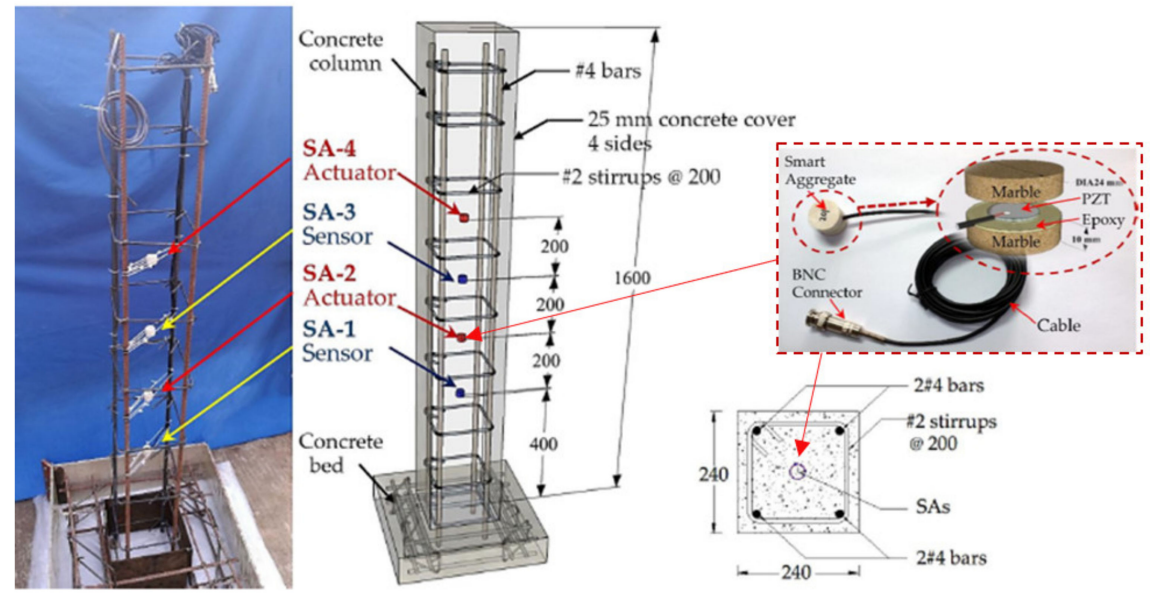

Figure 16. Position and appearance of the SA sensors [45].

Vapper and Lasn [31] examined columns measuring $100 \mathrm{~mm} \times 100 \mathrm{~mm} \times 1000 \mathrm{~mm}$ on the action of a different amount of explosion placed at a vertical standoff distance of $300 \mathrm{~mm}$. They tested four types of columns: reinforced concrete columns, columns reinforced with steel fibers, and both types strengthened with Glass Fiber Reinforced Polymer (GFRP). 
Plain concrete showed higher compressive strength compared to steel fiber reinforced concrete. GFRP in reinforced concrete columns did not contribute to the increase in the residual strength, while in steel fiber reinforced columns, the contribution was significant. A reduction in surface damage to GFRP-wrapped columns was also observed.

\section{Numerical Modeling}

Due to the increasing number of terrorist attacks, new challenges were posed to engineers. It is necessary to have a good understanding of computer programs, their capabilities, and their limitations to predict individual attack scenarios. The use of numerical simulations gives a clearer insight into the blast effects on the entire bridge and individual components. It provides the possibility of determining the most critical parts and problems that cannot be numerically simulated and need to be examined experimentally. Thus, one of the most important and difficult parts of this analysis is to properly define air blast loadings. Table 4 summarizes the software used to predict the effects of explosions on different types of columns.

Table 4. Summary of software for prediction and calculation of blast loads.

\begin{tabular}{|c|c|c|c|}
\hline Author & Year & Structural Element & Software \\
\hline Ray et al. [46] & 2003 & Bridge deck and column & ConWep, BlastX, SHAMRC \\
\hline Marchand et al. [36] & 2004 & Bridge columns & BlastX, ConWep, SPAn32 \\
\hline Winget et al. [2] & 2005 & Bridge concrete girders, deck, columns & BlastX, SPAn32, Nonlin \\
\hline Rutner et al. [47] & 2006 & Steel and composite bridge columns & MSC.Dytran \\
\hline Wu et al. [48] & 2009 & RC and composite building columns & LS-Dyna \\
\hline Hao et al. [49] & 2010 & RC building columns & CARLER \\
\hline Elsanadedy et al. [50] & 2011 & RC building columns + CFRP & LS-Dyna \\
\hline Williams et al. [51] & 2011 & RC bridge columns & LS-Dyna \\
\hline Williams et al. [52] & 2011 & $\mathrm{RC}$ bridge columns & LS-Dyna \\
\hline Crawford [10] & 2013 & $\mathrm{RC}$ building columns $+\mathrm{FRP}+\mathrm{SJ}$ & LS-Dyna \\
\hline Magali et al. [53] & 2013 & RC building columns & Abaqus \\
\hline Eisa [54] & 2014 & RC building columns & Abaqus \\
\hline Abladey and Braimah [55] & 2014 & RC building columns & Autodyn \\
\hline $\mathrm{Li}$ and Hao [56] & 2014 & RC column & LS-Dyna \\
\hline Shi and Stewart [57] & 2015 & RC building column & LS-Dyna \\
\hline Liu et al. [58] & 2015 & $\mathrm{RC}$ bridge pier-bent model & LS-Dyna, ConWep \\
\hline Cui et al. [59] & 2015 & $\mathrm{RC}$ column & LS-Dyna \\
\hline Zhang et al. [12] & 2015 & CFST building columns & LS-Dyna \\
\hline Codina et al. [14] & 2016 & RC building column & Autodyn \\
\hline Zhang et al. [21] & 2016 & CFDST columns & LS-Dyna \\
\hline Arowojolu et al. [60] & 2017 & $\mathrm{RC}$ bridge column & LS-Dyna \\
\hline Eamon and Aslendi [61] & 2017 & $\mathrm{RC}$ bridge columns $+\mathrm{SFRP}$ & LS-Dyna \\
\hline Kravchenko et al. [62] & 2017 & RC building columns & LS-Dyna \\
\hline Kyei and Braimah [63] & 2017 & RC building columns & LS-Dyna \\
\hline Yuan et al. [23] & 2017 & RC bridge columns & LS-Dyna \\
\hline Abedini et al. [64] & 2018 & RC building columns & LS-Dyna \\
\hline Li et al. [65] & 2018 & CFDST bridge columns & LS-Dyna \\
\hline Liu et al. [66] & 2018 & RC bridge piers & LS-Dyna, ConWep \\
\hline Li et al. [67] & 2019 & CFDST bridge columns & LS-Dyna \\
\hline Liu et al. [68] & 2019 & RC building columns & Autodyn, LS-Dyna \\
\hline Liu et al. [69] & 2019 & $\mathrm{RC}$ bridge column $+\mathrm{CFRP}$ & LS-Dyna \\
\hline Thai et al. [70] & 2019 & $\mathrm{RC}$ column $+\mathrm{SJ}$ & LS-Dyna \\
\hline Abedini et al. [71] & 2019 & RC column & LS-Dyna \\
\hline Dua et al. [72] & 2019 & RC columns & LS-Dyna \\
\hline Dua et al. [28] & 2020 & RC columns & LS-Dyna \\
\hline Li et al. [73] & 2020 & CFDST columns & LS-Dyna \\
\hline Rajkumar et al. [74] & 2020 & RC columns & LS-Dyna \\
\hline Vavilala et al. [75] & 2020 & $\mathrm{RC}$ building columns + polymeric foam & Abaqus \\
\hline Zhang et al. [76] & 2020 & Segmental CFST column & LS-Dyna \\
\hline Yuan et al. [77] & 2020 & RC column & LS-Dyna \\
\hline Yan et al. [78] & 2020 & RC columns + CFRP & LS-Dyna \\
\hline Hu et al. [79] & 2021 & RC column + CFRP & LS-Dyna \\
\hline
\end{tabular}

Note: CFRP—Carbon Fiber Reinforced Polymer; FRP—Fiber-Reinforced Plastic; SJ-Steel Jacket; CFST—Concrete-Filled Steel Tube; CFDST-Concrete-Filled Double Steel Tube; SFRP_Steel Fiber Reinforced Polymer. 
Conventional Weapon Effects Predictions (ConWep) [80] and BlastX [81] are programs used to calculate the effect of a blast wave from different types of detonation. ConWep is more used for air-blast calculations, including free-field and reflected blast pressure histories from the free-air, surface, and hemispherical burst explosions, and BlastX calculates internal blast pressure histories. Blast $X$ is based on semi-empirical methods, including nonlinear addition laws for blast pressures from multiple reflecting surfaces based on computational fluid dynamics. Second-order Hydrodynamic Automatic Mesh Refinement Code (SHAMRC) [82] is also used to investigate high explosive and blast effects based on finite-difference computational fluid dynamics (CFD) code. Nonlin [83] does not make the empirical adjustments just for blast loads because it is initially designed for earthquake loads. It has similarities with SPAn32 [84] because it performs a nonlinear dynamic response history analysis taking bilinear material properties. Both programs are based on the analysis of a system with a single degree of freedom (SDOF). MSC.Dytran [85] is an explicit finite element analysis (FEA) solution for simulating blast load effects and analyzing the complex nonlinear behavior that structures undergo during detonation. Ansys Autodyn [86], LS-Dyna [87], and Abaqus [88] are programs that provide the ability to simulate detonation, wave propagation from an explosion, interaction with a structure, and nonlinear material behavior, which are known as hydrocode programs specialized for simulations in fluid dynamics.

Ray et al. [46], in their research, compared three methods with three different resolutions for air blast prediction. In the scenario of below-deck detonation, ConWep has a low resolution of air blast prediction, and the charge can be observed as hemispherical or spherical, while BlastX has a medium resolution and considers the shape of the charge and reflections of the blast pressure. The 3D bridge and blast load can be modeled in the SHAMRC because it is an advanced Eulerian-based finite difference code that has high resolution. Research shows that the highest resolution is not always necessary, as it is a mostly low resolution that provides a conservative design. The authors stated that additional analysis is needed to determine the most economical and sufficiently precise tool for a particular problem [46]. The shape of the explosive also drastically affects the resulting pressure and impulse, so it is necessary to use a program that allows the input of charge geometry.

Marchand et al. [36] determined concrete breaching using ConWep and calculated flexural response and support rotation on a reduced diameter column in SPAn32. They concluded that the strength of concrete does not significantly affect the maximum rotation of the support, but it does affect breaching, i.e., the lower strength causes greater breaching.

Winget et al. [2] use SPAn32 to calculate the flexural response of the columns and to define the equivalent SDOF stiffness and mass parameters based on the column properties. For the calculation of the blast load pressure history, the BlastX program was used. Other useful programs are AT Blast [89] and Nonlin. For the calculation of the pressure-impulse history using AT Blast, it is necessary to know the charge weight, angle of incidence, and standoff distance. However, AT Blast does not consider the effects of multiple reflections under the bridge explosions. They list four categories of bridge design concerning their importance, where category 1 represents very important bridges, and category 4 , unimportant. Winget et al. did not take the real conditions of the ground and energy absorption by creating craters but the ideal reflecting surface. Footing instability, however, could also result from large ground deformations, and this aspect of behavior must also be addressed.

Wu et al. [48] numerically simulated RC and composite columns in LS-Dyna for the contact-placed TNT charges from 2.5 to $25 \mathrm{~kg}$. In the simulations, they obtained a higher residual bearing capacity of the column when the explosive was placed at the height of $1.5 \mathrm{~m}$ from the bottom than when it was placed at the bottom.

Fujikura et al. [7], for calculation of impulse variations per unit length along the height of the column, were using the Bridge Explosive Loading (BEL) [90] program. BEL also considers the reflected pressure of the blast wave on the surface of the superstructure and on the ground. 
Rutner et al. [47] studied the behavior of four types of column cross-sections in MSC.Dytran software on blast load: single-cell hollow steel section, multi-cell hollow steel section, single-cell hollow composite column, and multi-cell composite column. Compared to steel columns, the composites showed negligible deflection on blast load. The best stress distribution in the element was achieved with multi-cell composite columns, which is also visible by the displacements shown in Figure 17.

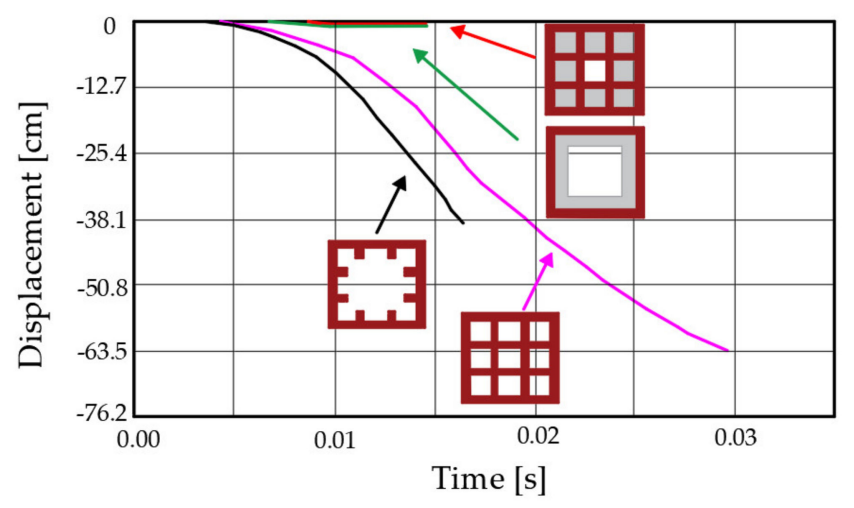

Figure 17. Time history of displacements for 4 column types [47].

Hao et al. [49] analyzed three reinforced concrete columns with the same dimensions, material strengths, and reinforcement ratios but subjected to blast loads of different scaled distances. They wanted to find the failure probability using the computer code CARLER, which is verified with Monte Carlo simulations. They defined four damage levels $(D)$ that depend on the ratio of residual axial load carrying capacity $\left(N_{\text {residual }}\right)$ when the column is damaged and the axial load of the undamaged column $\left(N_{0}\right)$, shown in Table 5 . Through numerical simulations, they concluded that neglecting some of the material properties of the column has minimal impact on the probability of failure, while the random changes in the blast loading have a much greater role.

Table 5. Damage levels of RC column in terms of axial load capacity.

\begin{tabular}{ccc}
\hline Level of Damage [49] & $D=1-\frac{N_{\text {residual }}}{N_{0}}$ & Damage Limit States [57] \\
\hline Low damage & $0-0.2$ & Low damage \\
Medium damage & $0.2-0.5$ & Repairable damage \\
High damage & $0.5-0.8$ & Repairable damage \\
Collapse & $0.8-1.0$ & Collapse \\
\hline
\end{tabular}

Williams and Williamson [51] emphasized the spalling of side-cover concrete because, in previous works, only the spalling of concrete off the back of reinforced concrete columns was mentioned. The aim of their research was to make and validate a numerical model with respect to the experiment explained in [38] and justified the cross-sectional response mechanisms that cause loss of side-cover concrete. For numerical simulations, they used the LS-Dyna program and the Karagozian and Case concrete (KCC) material model.

Numerical simulations in LS-Dyna showed that the shape of the column cross-section has a large influence on the resulting impulse. The authors developed expressions for calculating column shape factors for circular and square columns. The expressions are used when the $\mathrm{R} / \mathrm{D}$ ratio is less than 4.5 because they provide sufficiently conservative loads but less than those experimentally determined on the walls [52].

Crawford [10] performed numerical simulations in LS-Dyna of RC columns and columns retrofitted with fiber-reinforced plastic (FRP). FRP increases the resistance of the RC columns to the blast load. For numerical modeling, the choice of concrete material model is very important, and the analysis was performed with four different concrete 
models (KC, Winfrith, Continuous Smooth Cap, and RHT model). The best results were obtained with the KC model.

Magali et al. [53] performed a parametric numerical analysis in Abaqus to see which of the six varied parameters (section ratio, compressive strength of concrete, column height and thickness, charge radius, and ratio between standoff distance to the charge radius) had the greatest impact on column damage. It was shown that the column thickness, charge radius, and the ratio of standoff distance to charge radius play a significant role in the column response. They give an empirical formula based on the conducted simulations to predict the damage index of the column. Comparing the results obtained by formula and numerical simulations, the deviations are up to a maximum of $15 \%$ what is in an acceptable range.

Eisa [54] modeled RC columns in Abaqus. The position of the spherical charge remained unchanged, but the charge weight, column height, longitudinal steel reinforcement, columns aspect ratio, and transverse steel ratio were varied. Fixed boundary conditions are provided at the top and bottom of the column. In addition to column damage, they measured acceleration and displacement concerning varied parameters. Four quantities of explosives were used $(45.36,226.80,453.59$, and $1016.05 \mathrm{~kg})$ and placed at a distance of $4.87 \mathrm{~m}$. The increase in the lateral reinforcement in the column had the effect of reducing the displacement in the middle of the column. It is recommended to examine the influence of the axial force during the blast load and to include additional parameters such as the variation in the standoff distance of the charge.

In numerical simulations using Autodyn, Abladey and Braimah [55] tested three columns designed for different loads in accordance with the Canadian reinforced concrete design code [91]. The first type of column is designed only for gravity loads, and the distance between the transverse reinforcement is $300 \mathrm{~mm}$, and the other two types of columns are designed for seismic loads, but in the second type, the distance between transverse reinforcement is $150 \mathrm{~mm}$, and in the third $75 \mathrm{~mm}$. Column damage is significantly less with denser reinforcement, especially at small-scaled distances. They have proven in research that regardless of the same scaled distance, in a situation where a larger amount of explosive is detonated, the column has a higher deflection.

$\mathrm{Li}$ and Hao [56] calibrated the numerical model for RC slab in LS-Dyna according to a previously performed experiment and then used that numerical model for RC column simulation. For good simulation of concrete spallation, the erosion criterion using principle tensile strain of 0.01 was defined. Through simulations, they concluded that denser reinforcement and greater column depth reduced spall damage, i.e., increase the confinement of concrete. The boundary conditions and column height do not play a significant role in the level of spall damage in close-in cases.

Shi and Stewart [57] analyzed a spatial and non-spatial simulation of the blast load on RC columns in LS-Dyna. They used three quantities of ANFO explosives, 50, 100, and $1000 \mathrm{~kg}$, at distances from 0 to $30 \mathrm{~m}$. The analysis is based on axial load-carrying capacity and concluded that the variability of the results in the spatial model is lower, and the probability of damage is significantly higher. They consider the spatial model more reliable and recommended it for future research with an additional assessment of the scale of fluctuation.

Elsanadedy et al. [50] used LS-Dyna for analyzing the behavior of the exterior building RC circular column and strengthened column with Carbon Fiber Reinforced Polymer (CFRP) sheets under blast load. Four different charge weights (100, 200, 500, and $1000 \mathrm{~kg}$ ) of TNT at three different standoff distances $(1,4$, and $15 \mathrm{~m})$ and at $1 \mathrm{~m}$ height from the ground were analyzed. They modeled columns with different boundary conditions, first with both fixed ends and a second type with both hinged ends. For calculation of blast load parameters in all assumed scenarios, they used the software ConWep. The use of CFRP is increasing the shear capacity of the column and the strength of the column, which results in less lateral displacement, and more layers of CFRP can undergo more intense 
blast loads [50]. Moreover, at the scaled distance from 0.50 to $0.68 \mathrm{~m} / \mathrm{kg}^{1 / 3}$, columns with CFRP showed better behavior than RC columns.

Ashalekshmi and Subha [92] modeled a bridge column in the Ansys Autodyn software to analyze the impact of concrete grade and spacing of ties under the blast load. They observed total deformation and principal stress for concrete grades M40 and M50 and ties spacings of 10 and $20 \mathrm{~cm}$ in the near and far-field. In the near field, the explosive is placed at the same standoff distance of $2 \mathrm{~m}$, and the charge weight varies from 250 to $1500 \mathrm{~kg}$. The influence of the concrete grade on the maximum deformation is visible only at the weight of explosives greater than $750 \mathrm{~kg}$. With concrete M50, the principal stress is higher, but there is no big difference in it when increasing the weight of explosives. In the far-field, the explosive was placed at a standoff distance of $10 \mathrm{~m}$, and the weight also varied from 250 to $1500 \mathrm{~kg}$. There is a slight difference in total deformation concerning the grade of concrete. The principal stress exceeds the strength of concrete, and the difference in stress is visible for the grade of concrete. The effect of tie spacing is visible in the near field only in the increase in the maximum principal stress, while in the far-field, there is no effect on either deformation or principal stress.

Liu et al. [58] modeled the bridge column and bent it in the LS-Dyna for three design categories provided in [35]. They determined six damage mechanisms in the models, four of the column and two of bent. In all three design categories (A, B, C), spalling of concrete and crushing of the bent concrete were observed. Plastic joints in the column and shear of bent occur only in B and C categories. The shear or flexure failure of the column is most probable in category $C$, i.e., at the highest blast load. They found that increasing the transverse reinforcement reduces damage. In LS-Dyna, they received underestimated blast load, and therefore they used the ConWep program to calculate pressure-time diagrams.

Cui et al. [59] concluded through numerical simulations of columns in LS-Dyna that a larger cross-section and reinforcement ratio, smaller spacing between the stirrups, and a thinner concrete cover for columns exposed to close-in explosions give less damage.

Zhang et al. [12] analyzed circular and square CFST (Concrete Filled-Steel Tube) columns with tube thicknesses of 2.8 and $3.8 \mathrm{~mm}$. The Emulsion explosive was used, with TNT equivalences of $(0.7) 17.5,25$, and $35 \mathrm{~kg}$. A numerical simulation of the columns was performed in LS-Dyna, see Figure 18, but to reduce the computation time and model congestion, an air blast model was made in the ConWep program and then imported into LS-Dyna. By comparing the obtained periods of oscillation and maximum displacements, a good match between the numerical model and the experiment was obtained. Differences are found only in residual deflections but are not considered crucial to the accuracy of the model.

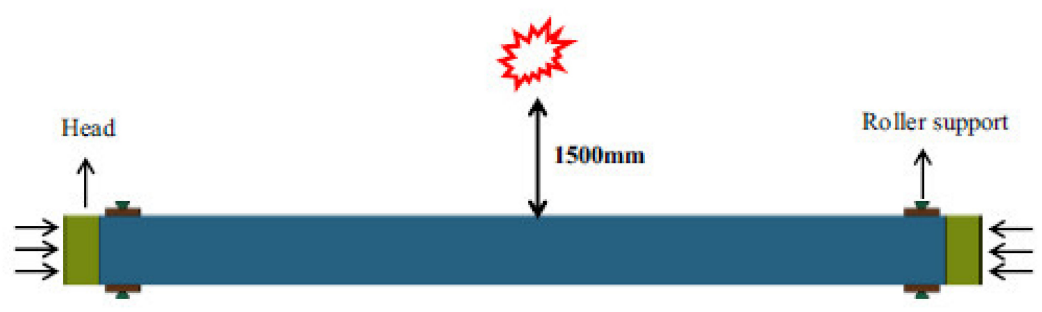

Figure 18. The numerical model of the blast test [12]. Copyright permission obtained from authors.

Zhang et al. [21] numerically modeled CFDST columns with steel-fiber reinforced concrete using LS-Dyna and compared them with experimentally obtained results. For concrete, the KC model was used, and for the steel tube, the Material model 24 was used. The parameters for the concrete model were modified $\left(f_{\mathrm{t}}\right.$-tensile strength, $B_{1}$ - parameter for residual strength, $w_{\mathrm{lz}}$ - strain softening, $\omega$-confinement effect, $\lambda$, and $\eta$-damage parameters) because UHPC was used. Column erosion occurs when the maximum shear strain value reaches 0.045 . Numerical research concluded that the axial load up to a certain limit has a favorable effect on the deflection in the middle of the column. It is 
not recommended to use columns with a hollow section ratio greater than 0.5 . Increasing the thickness of the outer steel tube affects the decrease in deflection in the middle of the column. Columns filled with UHPC have less plastic deformation than columns filled with normal strength concrete, shown in Figure 19.

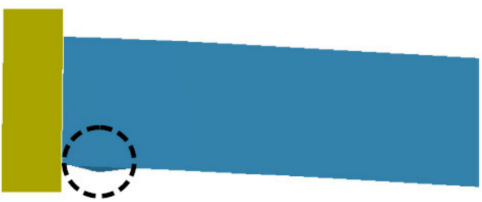

(a)

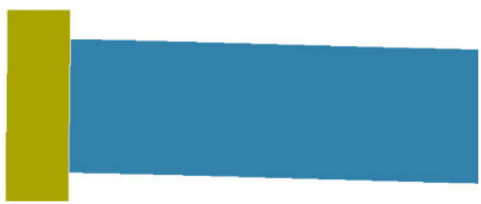

(b)

Figure 19. Failure mode of CFDST column with: (a) normal strength concrete and (b) UHPC [21]. Copyright permission obtained from authors.

Codina et al. [14] compared the numerical simulation with an already conducted experiment. The used explosive was Gelamon VF65 (65\% TNT equivalence), $8 \mathrm{~kg}$ TNT equivalence at distances of $1 \mathrm{~m}$ and $0.60 \mathrm{~m}$ from the column, which is classified as a near-field range. Overpressure, impulse, deflection, acceleration, and visual damage to the column were measured and compared. For numerical modeling, the Ansys Autodyn program was used in which air and explosives were modeled through an Euler processor and the column through Lagrange. The optimal mesh size of concrete, steel, and the air was $10 \mathrm{~mm}$. The authors made models with default RHT values and with the values proposed in [93] but concluded that the parameters that affect the strength degradation (damage factors $D_{1}$ and $D_{2}$, and $e_{\text {min }}^{\text {fail }}$ ) and the residual strength, $Y^{*}$ fric (parameters $B$ and $M$ ) should be changed in the model. For good prediction of spallation, the instantaneous geometric strain was used for erosion type with a value of 0.5 . The obtained column damage with different RHT parameters is shown in Table 6. The parameters of the RHT material model (shown in Table 3) are validated for scaled distances $(Z)$ from 0.5 to $0.3 \mathrm{~m} / \mathrm{kg}^{1 / 3}$.

Table 6. Column damage obtained: (a) experimentally and numerically using (b) default RHT model parameters; (c) parameters provided in [93]; (d) modified parameters by [14].

\begin{tabular}{|c|c|c|c|}
\hline $\begin{array}{l}\text { Parameters } \\
\text { (a) }\end{array}$ & Autodyn (Default) [86] (b) & $\begin{array}{l}\text { Tu and } L u[93] \\
\text { (c) }\end{array}$ & $\begin{array}{c}\text { Codina et al. [14] } \\
\text { (d) }\end{array}$ \\
\hline$B$ & 1.6 & 0.7 & 0.35 \\
\hline$M$ & 0.61 & 0.8 & 0.55 \\
\hline \multicolumn{4}{|c|}{ RHT damage model } \\
\hline$D_{1}$ & 0.04 & 0.015 & $0 . .8$ \\
\hline$D_{2}$ & 1 & 1 & 1 \\
\hline$e_{\text {min }}^{\text {fail }}$ & 0.01 & $8.00 \times 10^{-4}$ & 0.03 \\
\hline
\end{tabular}

Arowojolu et al. [60] studied, using LS-Dyna numerical models, the influence of axial and blast load on the RC column of the bridge. For the concrete model, they used CSCM (Continuous Surface Cap Model) and for reinforcement MAT 24. Exact quantities of explosives and distances are not given, but scaled distances from 1.77 to $0.45 \mathrm{~m} / \mathrm{kg}^{1 / 3}$. They concluded that when an axial load ratio of 0.25 is applied, the displacement in the middle of the column decreases but the damage of the column increases.

Eamon and Aslendi [61] made a numerical model of the column, experimentally tested in [4] using LS-Dyna software. The influence of concrete strength, reinforcement ratio, axial load, and the column wrapping with SFRP (Steel Fiber Reinforced Polymer) was 
observed. The Johnson-Holmquist-Cook (JHC) model was used for concrete modeling and the elastic-plastic kinematic model for steel reinforcement. The impact of the blast load was determined in the ConWep software, and the detonation point was placed $5 \mathrm{~cm}$ above the ground, $40 \mathrm{~cm}$ from the column. SFRP proved to be an inexpensive and ductile retrofit. One layer has the largest contribution in blast capacity, while all additional layers have a small effect on increasing the capacity. They obtained a linear relationship between the concrete strength and the increase in the blast load capacity.

Kravchenko et al. [62] performed numerical simulations of the RC column in LSDyna. The concrete was modeled using the CSCM concrete model (type 159 material) and reinforced using the plastic-kinematic model (type 3 material). They observed the influence of detonation of $10 \mathrm{~kg}$ of TNT at a distance of $1.2 \mathrm{~m}$ from the ground and $1 \mathrm{~m}$ from the column. They also concluded that the reinforcement ratio has a significant impact on the behavior of columns under the blast load and that the columns in the ground floor and bases need to be better reinforced due to their easy accessibility.

Kyei and Braimah [63] modeled three RC columns in LS-Dyna, which differ in the distance between the transverse reinforcement. They designed the columns according to the instructions for the level of seismicity in the Canadian concrete design code [91]. Concrete was modeled using the Continuous Surface Cap Model (MAT_CSCM_159), and for reinforcement, they used Material Piecewise Linear Plasticity (MAT_024) model, while blast load was calculated in ConWep and then imported with Load Blast Enhanced (LBE) in LS-Dyna. They performed simulations with mesh sizes from 5 to $100 \mathrm{~mm}$, and with $15 \mathrm{~mm}$, they obtained a good ratio of the time spent for the calculation and the accuracy of the results compared with the experiment in [94]. The used explosive was ANFO (100, 250, 500 , and $1000 \mathrm{~kg}$ ) at scaled distances of $0.8,1.0$, and $1.5 \mathrm{~m} / \mathrm{kg}^{1 / 3}$. In near-field explosions, the distance between the transverse reinforcement has a significant effect on the reduction in displacement, while in far-field explosions, this effect is negligible. At a high axial load ratio (0.35), the seismically designed columns showed better behavior at scaled distances than the standard ones.

Yuan et al. [23] performed numerical simulations in LS-Dyna of the circular and square columns of the bridge, exposed to the contact explosion of $1 \mathrm{~kg}$ of TNT. To reduce the computation time, at the height of $1 \mathrm{~m}$, in the area of the contact explosion, they placed a denser mesh $(8 \mathrm{~mm})$, while on the rest of the column, the mesh size was courser $(20 \mathrm{~mm})$, shown in Figure 20. The principal strain of 0.5 was used as the erosion criterion. Numerical simulations well described the damage on the front sides of the column, while on the back, there are differences. They concluded that the damage was greater on the square column due to the flat surface and the higher stress concentration than on the circular column. The damage of the columns is shown in Figure 21.

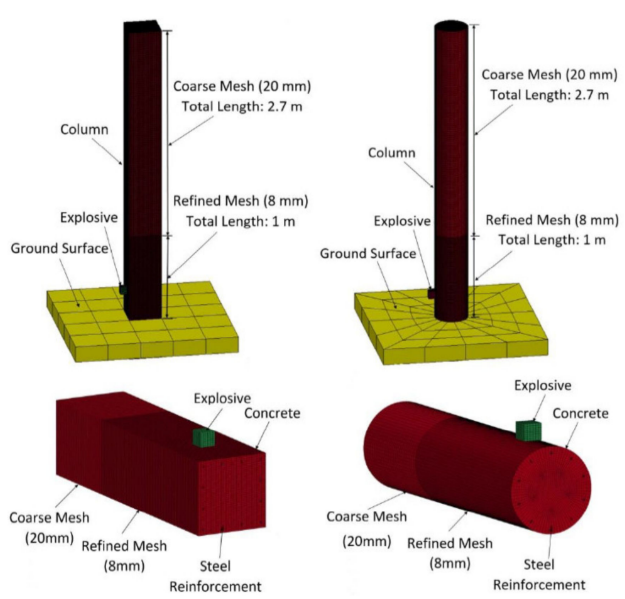

Figure 20. Detailed views of a mesh of 3D column models [23]. Copyright permission obtained from authors. 

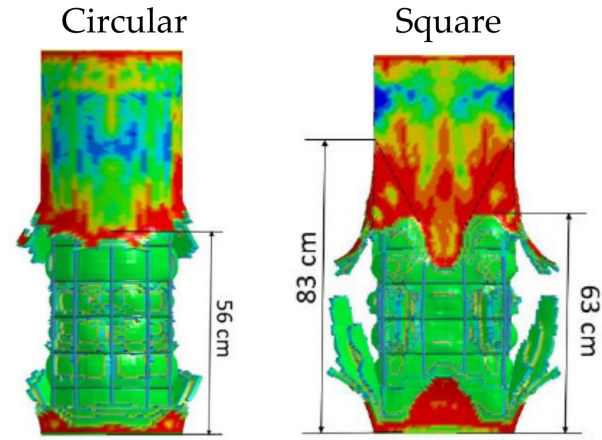

(a)

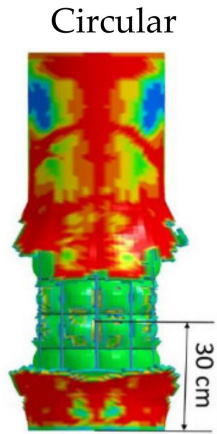

(b)

Figure 21. Comparison of damages of circular and square RC columns after the detonation of $1 \mathrm{~kg}$ of TNT: (a) front side and (b) back side [23]. Copyright permission obtained from authors.

Yuan et al. [77] investigated the effect of axial load on $\mathrm{RC}$ bridge columns subjected to far-field, close-in, and contact explosion. Columns in the far-field have mainly a flexure response, and the axial load affects the reduction in the maximum displacement in the middle of the column. In the case of a close-in detonation, a shear failure is expected, and the axial load affects the increase in the damage of the column and should not be neglected. In contact detonation, the concrete covers at the front and backside of the column spall off. The axial load reduces the damage of the concrete but increases the stress in the reinforcement and must be considered.

Li et al. [65] conducted numerical investigations on CFDST columns under contact explosion in LS-Dyna. CFDST columns have proven to be good for two reasons: the first is that the confinement of concrete by steel tube allows better energy absorption, and the second is the prevention of the spallation of the concrete cover. In work [73], the researchers concluded that increasing the cross-sectional area and the ratio of reinforcement plays a significant role in the post-blast residual capacity of CFDST columns under contact explosion. In [67], the behavior of CFDST columns subjected to close-in blast loading was studied. They concluded that the influence of the charge shape significantly affects the response and behavior of the column at scaled distances from $0.079 \mathrm{~m} / \mathrm{kg}^{1 / 3}$ to $0.175 \mathrm{~m} / \mathrm{kg}^{1 / 3}$.

Liu et al. [66] performed a dynamic and static analysis of the bridge columns in LSDyna. Dynamic analysis is based on the comparison of accelerations and static analysis on the determination of damage through the ratio of the residual to the ultimate axial bearing capacity. They examined the damage to the column concerning the position of the explosives, at the bottom, in the middle, and at the top, shown in Figure 22. In all three cases, bending deformation occurs at the column, but the position of the crack formation differs.

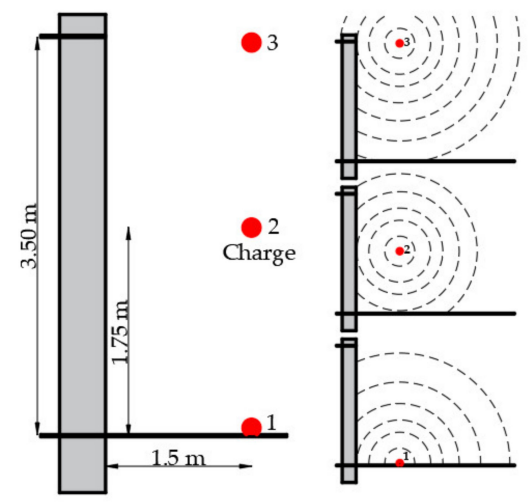

Figure 22. Shock wave propagation depending on the position of the explosive [66]. 
Liu et al. [68] performed a parametric analysis in LS-Dyna to determine the influence of longitudinal and transverse reinforcement ratios, longitudinal force, and boundary conditions. They concluded that at smaller-scaled distances, the increase in transverse and longitudinal reinforcement reduces the displacement in the middle of the column. It is recommended that the percentage of longitudinal reinforcement does not exceed $6 \%$ of the cross-sectional area of the column because too much reinforcement can lead to brittle failure. Analyzing the influence of the axial compressive load, they found that in an amount of up to $40 \%$, it reduces the maximum displacement in the mid-span of the column due to the increase in moment capacity. The conclusions are based on close-in blast loading; a recommendation for future research is to conduct a parametric analysis for near and far filed scenarios.

Liu et al. [69] made numerical models of RC columns strengthened with CFRP in LS-Dyna. The size of the mesh elements for all materials was $10 \mathrm{~mm}$, and for air, $20 \mathrm{~mm}$. The $1 \mathrm{~kg}$ and $2 \mathrm{~kg}$ TNT charges were placed in contact with the column at the height of $30 \mathrm{~cm}$. The numerical results show that the dragging force of the blast load separates the CFRP from the concrete, but despite this, CFRP protects the column from contact explosion. Column damage is shown in Figure 23.

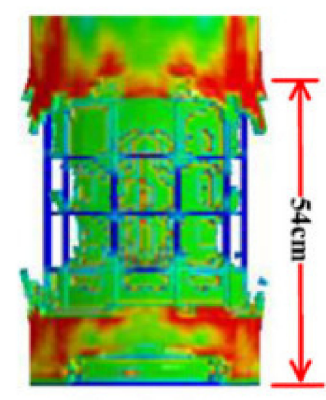

(a)

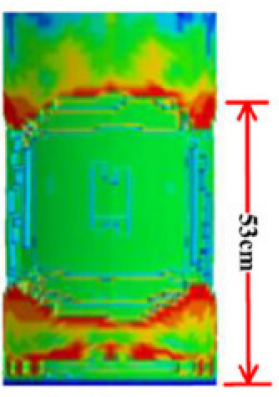

(b)

Figure 23. Column damages after detonation of $1 \mathrm{~kg}$ TNT: (a) RC and (b) RC + CFRP column [69]. Copyright permission obtained from authors.

Thai et al. [70] modeled in LS-Dyna RC steel jacked columns $(25 \mathrm{~cm} \times 25 \mathrm{~cm} \times 360 \mathrm{~cm})$ and observed the influence of steel thickness, scaled distance, and longitudinal compressive force on the behavior of the columns under the blast load. The columns are designed according to Eurocode 2. A $10 \mathrm{~mm}$ mesh was used for the column, while $5 \mathrm{~mm}$ elements were used for the explosive. Placing $8 \mathrm{~kg}$ of TNT in the middle of the column causes less global damage to the column, while placing the same amount at a distance of $32 \mathrm{~cm}$ from the ground causes significant local damage. The scaled distance was varied from 0.10 to $0.40 \mathrm{~m} / \mathrm{kg}^{1 / 3}$. Increasing the steel thickness from $3 \mathrm{~mm}$ to $6 \mathrm{~mm}$ did not result in less damage.

Abedini et al. [33] investigated numerically in LS-Dyna the influence of charge and scaled distance on the level of column damage and influence of column width, concrete strength, and reinforcement ratio on the residual axial load capacity.

Dua et al. [72] performed a parametric analysis in LS-Dyna on the RC columns exposed to the contact explosion. They used from $115 \mathrm{~g}$ to $1000 \mathrm{~g}$ TNT, varied the compressive strength of concrete from 20 to $55 \mathrm{MPa}$, and reduced the distance of the transverse reinforcement from 200 to $50 \mathrm{~mm}$. Increasing the transverse reinforcement reduces the damage to the concrete core, and higher compressive strength of concrete contributes to the reduction in cracks and peeling. The columns under contact explosion have local damage, while the global damage is negligible. Dua et al. [28] investigated in LS-Dyna the influence of the column cross-sectional width under the contact explosion. They concluded that a larger cross-sectional width (greater by two or more times from the depth) has a favorable effect on the behavior and damage of the column. 
Rajkumar et al. [74] examined 45 numerical models of reinforced concrete columns in scale 1:4 $(85 \mathrm{~mm} \times 85 \mathrm{~mm} \times 900 \mathrm{~mm})$ in LS-Dyna. In the models, the behavior of four different cross-sections (circular, octagonal, hexagonal and square) on the blast load was examined. The circular column retains the lowest peak pressures and has the smallest deflection in the middle, while the square has the highest pressures and the largest deflection. The edges in cross-sections at small-scaled distances play a significant role in pressure retention, while with increasing scaled distance, the shape influence decreases. An increase in reinforcement in cross-section affects the improvement of the behavior of the columns during the blast load, especially in shapes that retain higher pressures.

Vavilala et al. [75] numerically simulated polymeric foam retrofitted RC columns $(35.5 \mathrm{~cm} \times 35.5 \mathrm{~cm} \times 348 \mathrm{~cm})$ in Abaqus. They used a $10 \mathrm{~mm}$ mesh for reinforcement and $20 \mathrm{~mm}$ for concrete. Columns coated with $5 \mathrm{~mm}, 8 \mathrm{~mm}$, and $10 \mathrm{~mm}$ thick foam were exposed to 10, 25, and $50 \mathrm{~kg}$ of TNT. The greatest reduction in displacement in the middle of the column was obtained under $10 \mathrm{~kg}$ of TNT when the column was coated with $10 \mathrm{~mm}$ thick foam.

Zhang et al. [76] compare in LS-Dyna the behavior of a segmental CFST column with monolithic and prestressed monolithic columns. The columns were exposed to 20 and $50 \mathrm{~kg}$ of TNT at a standoff distance of $1.5 \mathrm{~m}$. The segmental column showed a smaller residual displacement, and numerical analysis proved that a larger number of segments had a more favorable effect on the behavior of the column. Moreover, increasing the steel thickness had a beneficial effect on reducing concrete damage.

Yan et al. [78] and $\mathrm{Hu}$ et al. [79] used LS-Dyna for numerical simulations of RC columns retrofitted with CFRP subjected to the close-in explosion. CFRP sheets reduce the deformation and spalling of concrete. The CFRP thickness, wrapping, and dimensions ratio of the charge also had a large impact on the damage of the column and peak pressure. Debonding of CFRP is the most common form of failure, but despite this, CFRP has a role in reducing column damage during the blast load, and it may even have a role in changing the failure mode from shear to flexural deformation. The setting of the CFRP on both sides of the column needs to be further investigated because direct shear is possible due to over-reinforcement.

\section{Discussion and Conclusions}

\subsection{Experimental Testing}

Most of the experiments were conducted for the scenario of an attack by an auto-bomb located near a bridge or building column. Experimental tests on building columns are mostly full-scale, while tests on bridge columns predominate on scales of 1:3 and 1:4, due to the high cost of performing such experiments, the need for trained personnel to handle explosives, large quantities of explosives, and the field where such tests can be carried out.

Experiments showed that even a minimal increase in the cross-sectional dimensions of a column could favorably affect the behavior of the column under the blast load. Moreover, a minimal increase in the standoff distance reduces the impact and intensity of the blast load, and therefore it is necessary whenever possible to fence the column, increase visibility around the column, and reduce its accessibility. In addition to the dimensions of the column, the shape of the column plays a significant role. Circular columns retain less impulse from the blast load than square ones of the same dimensions. Squares have a larger cross-sectional area and, therefore, can better withstand shear. On the action of the contact explosion, the circular column suffered less damage than the square. However, comparing a square and a rectangular column, when the width dimension of the rectangular column is greater two and more times from depth, damage of the column is lower. The shape of the column on the blast load needs to be further investigated. In RC columns, position, quantity, anchoring, and reinforcement overlap have a great impact. Therefore, seismically designed columns have better blast load behavior than standard designed columns.

Comparing steel jacked columns, CFST and CFDST with RC columns, all showed better ductility, less cracking of the concrete, and the absence of flying debris. However, 
CFDST showed the best behavior, as the inner steel tube contributes to the prevention of direct shear. With this type of column, it is important that the ratio of the cavity to the column cross-section is not greater than 0.5 and that the thickness of the steel tube is well determined (a thickness of $3.8 \mathrm{~mm}$ gave satisfactory results).

Columns with Ultra-High-Performance Concrete and with various Fiber-Reinforced Polymers showed better load-bearing capacity than High-Strength Reinforced Concrete.

The influence of axial load up to $30 \%$ of the total load capacity has shown a favorable effect on the reduction in the maximum displacement, but this percentage needs to be further investigated.

Recent research applies smart aggregates to measure internal cracks and internal damage because the column can be damaged and reduced load-bearing capacity without being visible on the outside. Therefore, post-blast tests are performed to determine the residual strength and ductility of the column.

\subsection{Numerical Modeling}

Numerical simulations make it possible to study the effect of large amounts of explosions (more than $1000 \mathrm{~kg}$ ) on columns in full-scale. The most widely used software for analyzing the nonlinear behavior of elements on blast load is LS-Dyna. The most accurate simulation of the blast pressure requires as finer mesh as possible, which leads to a long duration of simulations and congestion of the computer processor. Due to the use of a larger mesh size than recommended, the LS-Dyna underestimates the pressures. Most researchers use the ConWep program to calculate pressures and import the resulting pressures into LS-Dyna.

Defining a model of concrete material is the most demanding because many parameters affect its behavior. Karagozian and Case (KC) concrete is mostly used in LS-Dyna. The proper definition of erosion criteria has proven to be very important in modeling column damage.

The position of the explosive plays a significant role in the behavior of the column. Placing the charge in the far-field causes a uniformly distributed load per column and global response, while a charge placed in the near-field, close-in, and contact creates local damage.

Moreover, the columns exposed to the charge placed in the lower half showed greater damage and lowered residual capacity than the columns where the charge was placed in the middle.

In all fields (far, near, close-in), changes in the quantity, shape, and position of the explosives showed a great impact on column behavior. The shape of the column, the ratio of reinforcement, and the concrete grade showed an influence only at small-scaled distances. The concrete grade does not affect the rotation of the column but does affect the reduction in concrete breach and spallation.

Until recently, the axial load on bridge columns was neglected in the calculation because it was considered to be on the safe side. However, numerical simulations showed that axial load has a large impact on increasing damage when the charge is placed near the column or in contact with the column and should not be neglected.

Author Contributions: Conceptualization, S.L. and H.D.; methodology, S.L. and H.D.; resources, S.L. and H.D.; data curation, S.L.; writing-original draft preparation, S.L.; writing—review and editing, H.D.; visualization, S.L.; supervision, H.D.; project administration, H.D.; funding acquisition, H.D. All authors have read and agreed to the published version of the manuscript.

Funding: This research was in part funded by Croatian Science Foundation (HRZZ), grant number UIP-2017-05-7041.

Institutional Review Board Statement: Not applicable.

Informed Consent Statement: Not applicable. 
Data Availability Statement: Data available on request due to restrictions, e.g., privacy or ethics. The data presented in this study are available on request from the corresponding author. The data are not publicly available due to limited access to certain literature used in the article.

Acknowledgments: This paper has been supported in part by Croatian Science Foundation (HRZZ) under the project UIP-2017-05-7041 "Blast Load Capacity of Highway Bridge Columns", and support for this research is gratefully acknowledged.

Conflicts of Interest: The authors declare no conflict of interest.

\section{References}

1. START. National Consortium for the Study of Terrorism and Responses to Terrorism. Global Terrorism Database. 2017. Available online: https: / /www.start.umd.edu/gtd/ (accessed on 20 May 2020).

2. Winget, D.G.; Marchand, K.A.; Williamson, E.B. Analysis and design of critical bridges subjected to blast loads. J. Struct. Eng. 2005, 131, 1243-1255. [CrossRef]

3. Cooper, J.D.; Smith, M.C.; Ernst, S.L. Blue Ribbon Panel Recommendation for Bridge and Tunnel Security; The American Association of State Highway and Transportation Officials (AASHTO): Washington, DC, USA, 2003.

4. Williamson, E.B.; Bayrak, O.; Davis, C.; Williams, G.D. Performance of bridge columns subjected to blast loads. I: Experimental program. J. Bridge Eng. 2011, 16, 693-702. [CrossRef]

5. Fouché, P.; Bruneau, M.; Chiarito, V.P. Modified steel-jacketed columns for combined blast and seismic retrofit of existing bridge columns. J. Bridge Eng. 2016, 21, 4016035. [CrossRef]

6. Bruneau, M.; Lopez-Garcia, D.; Fujikura, S. Multihazard-resistant highway bridge bent. In Proceedings of the Structures Congress 2006: Structural Engineering and Public Safety, St. Louis, MN, USA, 18-21 May 2006; pp. 1-4.

7. Fujikura, S.; Bruneau, M.; Lopez-Garcia, D. Experimental investigation of multihazard resistant bridge piers having concrete-filled steel tube under blast loading. J. Bridge Eng. 2008, 13, 586-594. [CrossRef]

8. Davis, C.E.; Williams, G.D.; Williamson, E.B.; Marchand, K.A.; McKay, A.E.; Bayrak, O. Design and detailing guidelines for bridge columns subjected to blast and other extreme loads. In Proceedings of the Structures Congress 2009: Don't Mess with Structural Engineers: Expanding Our Role, Austin, TX, USA, 30 April-2 May 2009; pp. 1-10.

9. Fujikura, S.; Bruneau, M. Experimental investigation of seismically resistant bridge piers under blast loading. J. Bridge Eng. 2010, 16, 63-71. [CrossRef]

10. Crawford, J.E. State of the art for enhancing the blast resistance of reinforced concrete columns with fiber-reinforced plastic. Can J. Civil Eng. 2013, 40, 1023-1033. [CrossRef]

11. Burrell, R.P.; Aoude, H.; Saatcioglu, M. Response of SFRC columns under blast loads. J. Struct. Eng. 2015, 141, 4014209. [CrossRef]

12. Zhang, F.; Wu, C.; Wang, H.; Zhou, Y. Numerical simulation of concrete filled steel tube columns against BLAST loads. Thin Walled Struct. 2015, 92, 82-92. [CrossRef]

13. Aoude, H.; Dagenais, F.P.; Burrell, R.P.; Saatcioglu, M. Behavior of ultra-high performance fiber reinforced concrete columns under blast loading. Int. J. Impact Eng. 2015, 80, 185-202. [CrossRef]

14. Codina, R.; Ambrosini, D.; de Borbón, F. Experimental and numerical study of a RC member under a close-in blast loading. Eng. Struct. 2016, 127, 145-158. [CrossRef]

15. Codina, R.; Ambrosini, D.; de Borbón, F. Alternatives to prevent the failure of RC members under close-in blast loadings. Eng. Fail. Anal. 2016, 60, 96-106. [CrossRef]

16. Codina, R.; Ambrosini, D.; de Borbon, F. Alternatives to prevent progressive collapse protecting reinforced concrete columns subjected to near field blast loading. Procedia Eng. 2017, 199, 2445-2450. [CrossRef]

17. Xu, J.; Wu, C.; Xiang, H.; Su, Y.; Li, Z.-X.; Fang, Q.; Hao, H.; Liu, Z.; Zhang, Y.; Li, J. Behaviour of ultra high performance fibre reinforced concrete columns subjected to blast loading. Eng. Struct. 2016, 118, 97-107. [CrossRef]

18. Echevarria, A.; Zaghi, A.E.; Chiarito, V.; Christenson, R.; Woodson, S. Experimental comparison of the performance and residual capacity of CFFT and RC bridge columns subjected to blasts. J. Bridge Eng. 2016, 21, 4015026. [CrossRef]

19. Wang, J.; Chen, W.; Guo, Z.; Liang, W. Dynamic responses of RPC-filled steel tubular columns post fire under blast loading. Open Civil Eng. J. 2016, 10, 236-245. [CrossRef]

20. Zhang, F.; Wu, C.; Zhao, X.-L.; Xiang, H.; Li, Z.-X.; Fang, Q.; Liu, Z.; Zhang, Y.; Heidarpour, A.; Packer, J.A. Experimental study of CFDST columns infilled with UHPC under close-range blast loading. Int. J. Impact Eng. 2016, 93, 184-195. [CrossRef]

21. Zhang, F.; Wu, C.; Zhao, X.-L.; Heidarpour, A.; Li, Z. Experimental and numerical study of blast resistance of square CFDST columns with steel-fibre reinforced concrete. Eng. Struct. 2017, 149, 50-63. [CrossRef]

22. Codina, R.; Ambrosini, D.; de Borbón, F. New sacrificial cladding system for the reduction of blast damage in reinforced concrete structures. Int. J. Prot. Struct. 2017, 8, 221-236. [CrossRef]

23. Yuan, S.; Hao, H.; Zong, Z.; Li, J. A study of RC bridge columns under contact explosion. Int. J. Impact Eng. 2017, 109, 378-390. [CrossRef]

24. Wang, H.; Wu, C.; Zhang, F.; Fang, Q.; Xiang, H.; Li, P.; Li, Z.; Zhou, Y.; Zhang, Y.; Li, J. Experimental study of large-sized concrete filled steel tube columns under blast load. Constr. Build. Mater. 2017, 134, 131-141. [CrossRef] 
25. Li, J.; Wu, C.; Hao, H.; Liu, Z. Post-blast capacity of ultra-high performance concrete columns. Eng. Struct. 2017, 134, $289-302$. [CrossRef]

26. Fouché, P.; Bruneau, M.; Chiarito, V. Dual-hazard blast and seismic behavior of concrete-filled double-skin steel tubes bridge pier. J. Struct. Eng. 2017, 143, 4017155. [CrossRef]

27. Dua, A.; Braimah, A.; Kumar, M. Contact explosion response of reinforced concrete columns: Experimental and validation of numerical model. In Proceedings of the Paper presented at the 6th International Disaster Mitigation Specialty Conference, Fredericton, NB, Canada, 13-16 June 2018.

28. Dua, A.; Braimah, A.; Kumar, M. Experimental and numerical investigation of rectangular reinforced concrete columns under contact explosion effects. Eng. Struct. 2020, 205, 109891. [CrossRef]

29. Wang, Z.; Wu, H.; Fang, Q.; Wu, J. Experimental study on the residual axial capacity of ultra high performance cementitious composite filled steel tube (UHPCC-FST) column under contact explosion. Thin Walled Struct. 2020, 147, 106515. [CrossRef]

30. Kadhom, B.; Almansour, H.; Saatcioglu, M. Post-blast axial capacity of CFRP strengthened RC columns. In IOP Conference Series: Materials Science and Engineering, Proceedings of the 4th International Conference on Buildings, Construction and Environmental Engineering, Istanbul, Turkey, 7-9 October 2019; IOP Publishing Ltd.: Istanbul, Turkey, 2020; p. 012042.

31. Vapper, M.; Lasn, K. Blast protection of concrete columns with thin strips of GFRP overlay. Structures 2020, 25, 491-499. [CrossRef]

32. Williamson, E.B.; Winget, D.G. Risk management and design of critical bridges for terrorist attacks. J. Bridge Eng. 2005, 10, 96-106. [CrossRef]

33. Chipley, M. Reference Manual to Mitigate Potential Terrorist Attacks Against Buildings: Providing Protection to People and Building; Federal Emergency Management Agency: Washington, DC, USA, 2003.

34. Roberts, J.; Kulicki, J.; Beranek, D.A.; Englot, J.M.; Fisher, J.W.; Hungerbeeler, H.; Seible, F.; Stinson, K.; Tang, M.C.; Witt, K. Recommendations for Bridge and Tunnel Security; Federal Highway Administration (US): Washington, DC, USA, 2003.

35. Williamson, E.B.; Bayrak, O.; Davis, C.; Daniel Williams, G. Performance of bridge columns subjected to blast loads. II: Results and recommendations. J. Bridge Eng. 2011, 16, 703-710. [CrossRef]

36. Marchand, K.; Williamson, E.; Winget, D. Analysis of blast loads on bridge substructures. WIT Trans. Built Environ. 2004, 73. [CrossRef]

37. National Cooperative Highway Research Program. Blast-Resistant Highway Bridges: Design and Detailing Guidelines; Transportation Research Board: Washington, DC, USA, 2010.

38. Williams, G.; Holland, C.; Williamson, E.B.; Bayrak, O.; Marchand, K.A.; Ray, J. Blast-Resistant Highway Bridges: Design and Detailing Guidelines; Transportation Research Board; WIT Press: Southampton, UK, 2010; Volume 645.

39. Conrath, E.J. Structural Design for Physical Security: State of the Practice; ASCE, cop.: Reston, VA, USA, 1999.

40. Mays, G.; Smith, P.D.; Smith, P.D. Blast Effects on Buildings: Design of Buildings to Optimize Resistance to Blast Loading; Thomas Telford: Telford, UK, 1995.

41. US DoD. UFC 3-340-02: Structures to Resist the Effects of Accidental Explosions; US DoD.: Washington, DC, USA, 2008.

42. American Institute of Steel Construction. Seismic Provisions for Structural Steel Buildings; American Institute of Steel Construction: Chicago, IL, USA, 2010.

43. Fujikake, K.; Aemlaor, P. Damage of reinforced concrete columns under demolition blasting. Eng. Struct. 2013, 55, 116-125. [CrossRef]

44. Roller, C.; Mayrhofer, C.; Riedel, W.; Thoma, K. Residual load capacity of exposed and hardened concrete columns under explosion loads. Eng. Struct. 2013, 55, 66-72. [CrossRef]

45. Xu, K.; Deng, Q.; Cai, L.; Ho, S.; Song, G. Damage detection of a concrete column subject to blast loads using embedded piezoceramic transducers. Sensors 2018, 18, 1377. [CrossRef] [PubMed]

46. Ray, J.; Armstrong, B.; Slawson, T. Airblast environment beneath a bridge overpass. Transp. Res. Rec. J. Transp. Res. Board 2003, 1827, 63-68. [CrossRef]

47. Rutner, M.P.; Astaneh-Asl, A.; Son, J. Blast resistant performance of steel and composite bridge piers. In Proceedings of the IABSE Symposium Report, Munich, Germany, 29 August-1 September 2005; pp. 47-54.

48. Wu, K.-C.; Li, B.; Tsai, K.-C. The effects of explosive mass ratio on residual compressive capacity of contact blast damaged composite columns. J. Constr. Steel Res. 2011, 67, 602-612. [CrossRef]

49. Hao, H.; Stewart, M.G.; Li, Z.-X.; Shi, Y. RC column failure probabilities to blast loads. Int. J. Prot. Struct. $2010,1,571-591$. [CrossRef]

50. Elsanadedy, H.M.; Almusallam, T.H.; Abbas, H.; Al-Salloum, Y.A.; Alsayed, S.H. Effect of blast loading on CFRP-Retrofitted RC columns-a numerical study. Lat. Am. J. Solids Struct. 2011, 8, 55-81. [CrossRef]

51. Williams, G.D.; Williamson, E.B. Response of reinforced concrete bridge columns subjected to blast loads. J. Struct. Eng. 2011, 137, 903-913. [CrossRef]

52. Williams, G.D.; Williamson, E.B. Procedure for predicting blast loads acting on bridge columns. J. Bridge Eng. 2011, 17, 490-499. [CrossRef]

53. Magali, A.; Alain, R.; Chhim, S. Numerical dynamic simulations for the prediction of damage and loss of capacity of RC column subjected to contact detonations. In Fracture Mechanics of Concrete and Concrete Structures; IA-FraMCoS: Toledo, Spain, 2013.

54. Eisa, A.S. Finite element analysis of reinforced concrete columns under different range of blast loads. Int. J. Civ. Struct. Eng. 2014, $5,155$. 
55. Abladey, L.; Braimah, A. Near-field explosion effects on the behaviour of reinforced concrete columns: A numerical investigation. Int. J. Prot. Struct. 2014, 5, 475-499. [CrossRef]

56. Li, J.; Hao, H. Numerical study of concrete spall damage to blast loads. Int. J. Impact Eng. 2014, 68, 41-55. [CrossRef]

57. Shi, Y.; Stewart, M.G. Spatial reliability analysis of explosive blast load damage to reinforced concrete columns. Struct. Saf. 2015, 53, 13-25. [CrossRef]

58. Liu, H.; Torres, D.M.; Agrawal, A.K.; Yi, Z.; Liu, G. Simplified blast-load effects on the column and bent beam of highway bridges. J. Bridge Eng. 2015, 20, 06015001. [CrossRef]

59. Cui, J.; Shi, Y.; Li, Z.-X.; Chen, L. Failure analysis and damage assessment of RC columns under close-in explosions. J. Perform. Constr. Facil. 2015, 29, B4015003. [CrossRef]

60. Arowojolu, O.; Rahman, M.K.; Hussain, B.M. Dynamic response of reinforced concrete bridge piers subjected to combined axial and blast loading. In Proceedings of the Structures Congress 2017, Denver, CO, USA, 6-8 April 2017; pp. 98-109.

61. Eamon, C.; Alsendi, A. Resistance of Reinforced Concrete Bridge Columns Subjected to Blast Loads. 2017. Available online: http:/ / www.awarie.zut.edu.pl/files/ab2017/referaty/09/09-02\%20-\%20Eamon\%20C,\%20Aslendi\%20A\%20-\%20Resistance\% 20of\%20reinforced\%20concrete\%20bridge \%20columns\%20subjected\%20to\%20blast\%20loads.pdf (accessed on 1 June 2021).

62. Kravchenko, G.; Trufanova, E.; Kostenko, D.; Tsurikov, S. Analysis of blast load on a reinforced concrete column in the time domain. MATEC Web Conf. 2017, 106, 04019. [CrossRef]

63. Kyei, C.; Braimah, A. Effects of transverse reinforcement spacing on the response of reinforced concrete columns subjected to blast loading. Eng. Struct. 2017, 142, 148-164. [CrossRef]

64. Abedini, M.; Mutalib, A.A.; Raman, S.N.; Akhlaghi, E. Modeling the effects of high strain rate loading on RC columns using Arbitrary Lagrangian Eulerian (ALE) technique. Rev. Int. Métodos Numéricos Cálculo Diseño Ing. 2018, 34. [CrossRef]

65. Li, M.; Zong, Z.; Liu, L.; Lou, F. Experimental and numerical study on damage mechanism of CFDST bridge columns subjected to contact explosion. Eng. Struct. 2018, 159, 265-276. [CrossRef]

66. Liu, L.; Zong, Z.; Li, M. Numerical study of damage modes and assessment of circular RC pier under noncontact explosions. J. Bridge Eng. 2018, 23, 04018061. [CrossRef]

67. Li, M.; Zong, Z.; Hao, H.; Zhang, X.; Lin, J.; Xie, G. Experimental and numerical study on the behaviour of CFDST columns subjected to close-in blast loading. Eng. Struct. 2019, 185, 203-220. [CrossRef]

68. Liu, Y.; Yan, J.; Li, Z.; Huang, F. Improved SDOF and numerical approach to study the dynamic response of reinforced concrete columns subjected to close-in blast loading. Structures 2019, 22, 341-365. [CrossRef]

69. Liu, L.; Zong, Z.; Gao, C.; Yuan, S.; Lou, F. Experimental and numerical study of CFRP protective RC piers under contact explosion. Compos. Struct. 2020, 234, 111658. [CrossRef]

70. Thai, D.K.; Pham, T.H.; Nguyen, D.L. Damage assessment of reinforced concrete columns retrofitted by steel jacket under blast loading. Struct. Des. Tall Spec. Build. 2020, 29, e1676. [CrossRef]

71. Abedini, M.; Mutalib, A.A.; Mehrmashhadi, J.; Raman, S.N.; Alipour, R.; Momeni, T.; Mussa, M.H. Large deflection behavior effect in reinforced concrete columns exposed to extreme dynamic loads. Frontiers of Struct. Civ. Eng. 2020, 14, 532-553. [CrossRef]

72. Dua, A.; Braimah, A.; Kumar, M. Contact explosion response of RC columns: Experimental and numerical investigation. Proc. Inst. Civil Eng. Struct. Build. 2020, 173, 799-820. [CrossRef]

73. Li, M.; Zong, Z.; Hao, H.; Zhang, X.; Lin, J.; Liao, Y. Post-blast performance and residual capacity of CFDST columns subjected to contact explosions. J. Constr. Steel Res. 2020, 167, 105960. [CrossRef]

74. Rajkumar, D.; Senthil, R.; Bala Murali Kumar, B.; AkshayaGomathi, K.; Mahesh Velan, S. Numerical Study on Parametric Analysis of Reinforced Concrete Column under Blast Loading. J. Perform. Constr. Facil. 2020, 34, 04019102. [CrossRef]

75. Vavilala, S.; Shirbhate, P.; Mandal, J.; Dass Goel, M. Blast mitigation of RC column using polymeric foam. Mater. Today Proc. 2020, 26, 1347-1351. [CrossRef]

76. Zhang, X.; Hao, H.; Li, M.; Zong, Z.; Bruechert, J.W. The blast resistant performance of concrete-filled steel-tube segmental columns. J. Constr. Steel Res. 2020, 168, 105997. [CrossRef]

77. Yuan, S.; Hao, H.; Zong, Z.; Li, J. Numerical analysis of axial load effects on RC bridge columns under blast loading. Adv. Struct. Eng. 2021, 24, 1399-1414. [CrossRef]

78. Yan, J.; Liu, Y.; Xu, Z.; Li, Z.; Huang, F. Experimental and numerical analysis of CFRP strengthened RC columns subjected to close-in blast loading. Int. J. Impact Eng. 2020, 146, 103720. [CrossRef]

79. Hu, Y.; Chen, L.; Fang, Q.; Kong, X.; Shi, Y.; Cui, J. Study of CFRP retrofitted RC column under close-in explosion. Eng. Struct. 2021, 227, 111431. [CrossRef]

80. United States Department of the Army. Fundamentals of Protective Design for Conventional Weapons; United States Department of the Army: The Pentagon, VA, USA, 1986.

81. Britt, J.R.; Ranta, E.D.; Ohrt, A.P. User's Manual for the BlastX Code; Version 4.0.; U.S. Army Engineer Waterways Experiment Station: Vicksburg, MS, USA, 1998.

82. Crepeau, J. Second-Order Hydrodynamic Automatic Mesh Refinement Code; Volume 2: User's Manual; Applied Research Associates, Inc.: Albuquerque, NM, USA, 2001.

83. Advanced Structural Concepts, Incorporated. NONLIN 7.05; Advanced Structural Concepts, Inc.: Blacksburg, VA, USA, 2003.

84. US Army Corps of Engineers-Omaha District. O. Neb. (Distribution Limited to U.S. Government Agencies; Contractors), a.t. SPAn32; Version 1.2.6.9.; US Army Corps of Engineers-Omaha District: Omaha, NE, USA, 2002. 
85. MSC. Dytran Theory Manual; MSC. Software Corporation: Newport Beach, CA, USA, 2002.

86. Ansys Inc. Ansys Autodyn Users's Manual; Ansys Inc.: Canonsburg, PA, USA, 2010.

87. LS-DYNA; Version 971; Livermore Software Technology Corporation (LSTC): Livermore, CA, USA, 2007.

88. Smith, M. ABAQUS/Standard User's Manual; Version 6.9; Dassault Systèmes Simulia Corp: Providence, RI, USA, 2009.

89. Applied Research Associates, Inc. Anti-Terrorist Blast (AT-Blast); Version 2.1; Applied Research Associates, Inc.: Albuquerque, NM USA, 2004

90. U.S. Army Corps of Engineers, Engineer Research and Development Center. Bridge Explosive Loading (BEL); Version 1.1.0.3; Engineer Research and Development Center: Vicksburg, MS, USA, 2004.

91. Canadian Standards Association. Design and Assessment of Buildings Subjected to Blast Loads; CSA Group: Mississauga, ON, Canada, 2012.

92. Ashalekshmi, K.G.; Subha, K. Effect of grade of concrete and spacing of ties in the response of RCC bridge pier subjected to ground blast loading. Int. Res. J. Eng. Technol. 2018, 5, 2023-2029.

93. Tu, Z.; Lu, Y. Evaluation of typical concrete material models used in hydrocodes for high dynamic response simulations. Int. J. Impact Eng. 2009, 36, 132-146. [CrossRef]

94. Siba, F. Near-Field Explosion Effects on Reinforced Concrete Columns: An Experimental Investigation. Master's Thesis, Carleton University, Ottawa, ON, Canada, 2014. 